Prepared in cooperation with CITY OF WICHITA, KANSAS

\title{
Preliminary Assessment of Phosphorus Transport in the Cheney Reservoir Watershed, South-Central Kansas, 1997-98
}

Water-Resources Investigations Report 00-4023

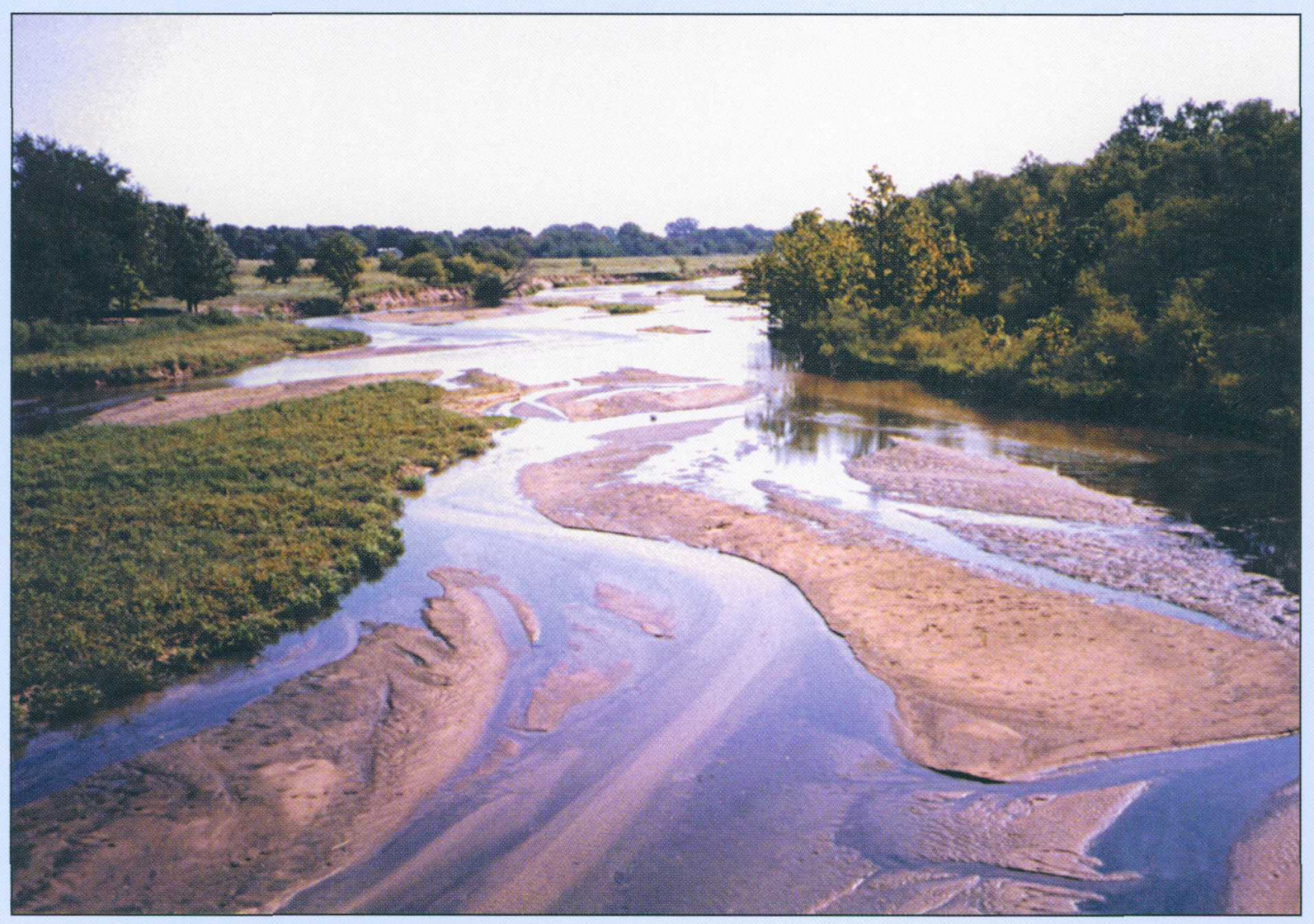


Cover photograph: North Fork Ninnescah River above Cheney Reservoir, Kansas (photograph by Chad Milligan, U.S. Geological Survey, Wichita, Kansas). 


\section{Preliminary Assessment of Phosphorus Transport in the Cheney Reservoir Watershed, South-Central Kansas, 1997-98}

By LARRY M. POPE and CHAD R. MILLIGAN

Water-Resources Investigations Report 00-4023

Prepared in cooperation with CITY OF WICHITA, KANSAS

Lawrence, Kansas

2000 


\section{U.S. Department of the Interior}

Bruce Babbitt, Secretary

\section{U.S. Geological Survey}

Charles G. Groat, Director

For additional information write to:

District Chief

U.S. Geological Survey

4821 Quail Crest Place

Lawrence, KS 66049-3839
Copies of this report can be purchased from:

U.S. Geological Survey

Information Services

Building 810 , Federal Center

Box 25286

Denver, CO 80225-0286 


\section{CONTENTS}

Abstract..und
Background
Significance of Phosphorus
Description of Study
Description of Cheney Reservoir Watershed
Study Methods
Phosphorus Transport
Comparison of Preliminary Results with Previous Studies in Kansas
References
Supplemental Information

\section{FIGURES}

1. Maps showing location of Cheney Reservoir watershed, sampling sites, and subwatershed areas, south-central Kansas

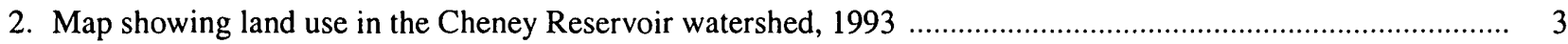

3-7. Graphs showing:

3. Livestock inventories in the Cheney Reservoir watershed for selected years between 1964 and 1996

4. Comparison of annual mean streamflow for 1997 and 1998 with long-term mean annual streamflow at two sampling sites on the North Fork Ninnescah River

5. Relation between phosphorus concentrations determined for manually and automatically collected concurrent samples at sampling sites 1-5 in the Cheney Reservoir watershed, 1997-98.

6. Comparison of 1997 and 1998 annual loads of phosphorus estimated for selected sampling sites or subwatershed areas in the Cheney Reservoir watershed.

7. Comparison of 1997 and 1998 annual phosphorus yields estimated for selected sampling sites or subwatershed areas in the Cheney Reservoir watershed..

8. Map showing distribution of mean annual phosphorus yields estimated for the Cheney Reservoir watershed, 1997-98

9. Graph showing comparison of mean annual water yield estimated for selected sampling sites and East Ninnescah subwatershed area in the Cheney Reservoir watershed, 1997-98.

10. Graph showing comparison of 1997 and 1998 estimated annual phosphorus inflow and outflow loads for Cheney Reservoir 


\begin{tabular}{rcl} 
CONVERSION FACTORS & & \\
\hline Multiply & By & To obtain \\
acre & 4,047 & square meter \\
acre-foot & 1,233 & cubic meter \\
acre-foot per square mile & 476.1 & cubic meter per square kilometer \\
cubic foot per second & 0.02832 & cubic meter per second \\
foot & 0.3048 & meter \\
gallon & 3.785 & liter \\
gram per second & 0.002205 & pound per second \\
inch & 2.54 & centimeter \\
mile & 1.609 & kilometer \\
pound & 0.4536 & kilogram \\
pound per acre & 1.121 & kilogram per hectare \\
square mile & 2.590 & square kilometer \\
\hline
\end{tabular}




\title{
Preliminary Assessment of Phosphorus Transport in the Cheney Reservoir Watershed, South-Central Kansas, 1997-98
}

\author{
By Larry M. Pope and Chad R. Milligan
}

\section{Abstract}

A 5-year assessment of water-quality conditions is being conducted in the 933-square-mile Cheney Reservoir watershed of south-central Kansas. Part of this assessment is to define source areas of phosphorus in the watershed and to quantify its transport into Cheney Reservoir. Concern exists for the quality of water in Cheney Reservoir particularly in regards to phosphorus because of its possible relation to algal blooms and subsequent taste and odor problems in treated drinking water from the reservoir. The purpose of this report is to present the results of a preliminary assessment of phosphorus transport during the first 2 complete years (1997-98) of data collection.

Annual phosphorus loads and yields were estimated, using regression analysis, at six sampling sites in the Cheney Reservoir watershed. Phosphorus loads and yields for the entire watershed also were estimated. Estimated phosphorus loads at all sampling sites and two additional subwatershed areas were substantially larger in 1998 than in 1997, with a median increase of 68 percent. This increase was mostly the result of wetter conditions in 1998. Estimated mean annual phosphorus yields for 1997-98 (upstream from Cheney Reservoir) ranged from 0.131 to 0.371 pound per acre. Much of the between-site variability in yields was attributed to variability in water yield and does not represent substantial changes in land-use or land-management practices. On average, about 62 percent of the phosphorus load to the reservoir was retained in the reservoir.

A mean annual phosphorus yield for 1997-98 for the entire Cheney Reservoir watershed was estimated at 0.20 pound per acre. This compares to mean annual phosphorus yields of 1.76 and 0.05 pounds per acre reported in previous reservoir watershed assessments conducted in the Hillsdale Lake watershed in eastern Kansas in 1996 and the Webster Reservoir watershed in western Kansas in 1998, respectively. However, because of some uncertainty of the representativeness of the Cheney Reservoir watershed mean annual yield for 1997-98, it is suggested that a detailed examination of reservoir bottom sediment and associated phosphorus might provide estimates of historical mean annual phosphorus loads to Cheney Reservoir and of yields from the watershed with which to compare results of the 1997-98 study.

\section{BACKGROUND}

\section{Significance of Phosphorus}

Phosphorus is a macronutrient required by plants for growth and reproduction. It is present in soil in organic forms and as inorganic aluminum, iron, manganese, and calcium phosphates. Phosphorus is necessary in cellular reactions involving photosynthesis, respiration, energy storage and transfer, and cell 
division, growth, and genetic coding (Sine, 1993, p. B46). Ecologically, phosphorus is the single most important factor in maintaining biogeochemical cycles because of its role in energy-transfer systems and its normally limited supply (Reid and Wood, 1976, p. 236). Phosphorus availability is a critical factor in the eutrophication (nutrient enrichment and seasonal deficiency of oxygen) of water bodies because the nutrient in shortest supply controls biological production rates (Hem, 1985, p. 128).

Phosphorus often is added to agricultural soils to stimulate plant growth and increase crop yields. It may be added as an inorganic phosphate or as a component of manure from confined animal-feeding operations or from human sewage disposal. However, the use of phosphorus as a fertilizer can have detrimental effects on water bodies receiving runoff from areas of application. Excessive phosphorus in water bodies can accelerate eutrophication, which is characterized by extensive algal growth (algal blooms) that may reduce the aesthetic and recreational value of water, produce taste and odor problems in drinking water, and, in severe cases, stress or kill aquatic organisms as a result of dissolved-oxygen depletion when algal populations die and decompose.

\section{Description of Study}

Cheney Reservoir in south-central Kansas (fig. 1) was constructed by the Bureau of Reclamation, U.S. Department of the Interior, in 1965 to serve as a watersupply source, to provide downstream flood control, to allow recreational activities such as boating and fishing, and to provide wildlife benefits. The reservoir has a conservation-pool surface area of about 15 square miles, a mean depth of about 16 feet, and a conservation-pool storage of 151,800 acre-feet with an additional flood-control pool capacity of 80,860 acre-feet. The city of Wichita acquires about 60 percent of its daily water supply from Cheney Reservoir, serving a population of more than 300,000 (Jerry Blain, city of Wichita, Kansas, Water and Sewer Department, oral commun., 1999).

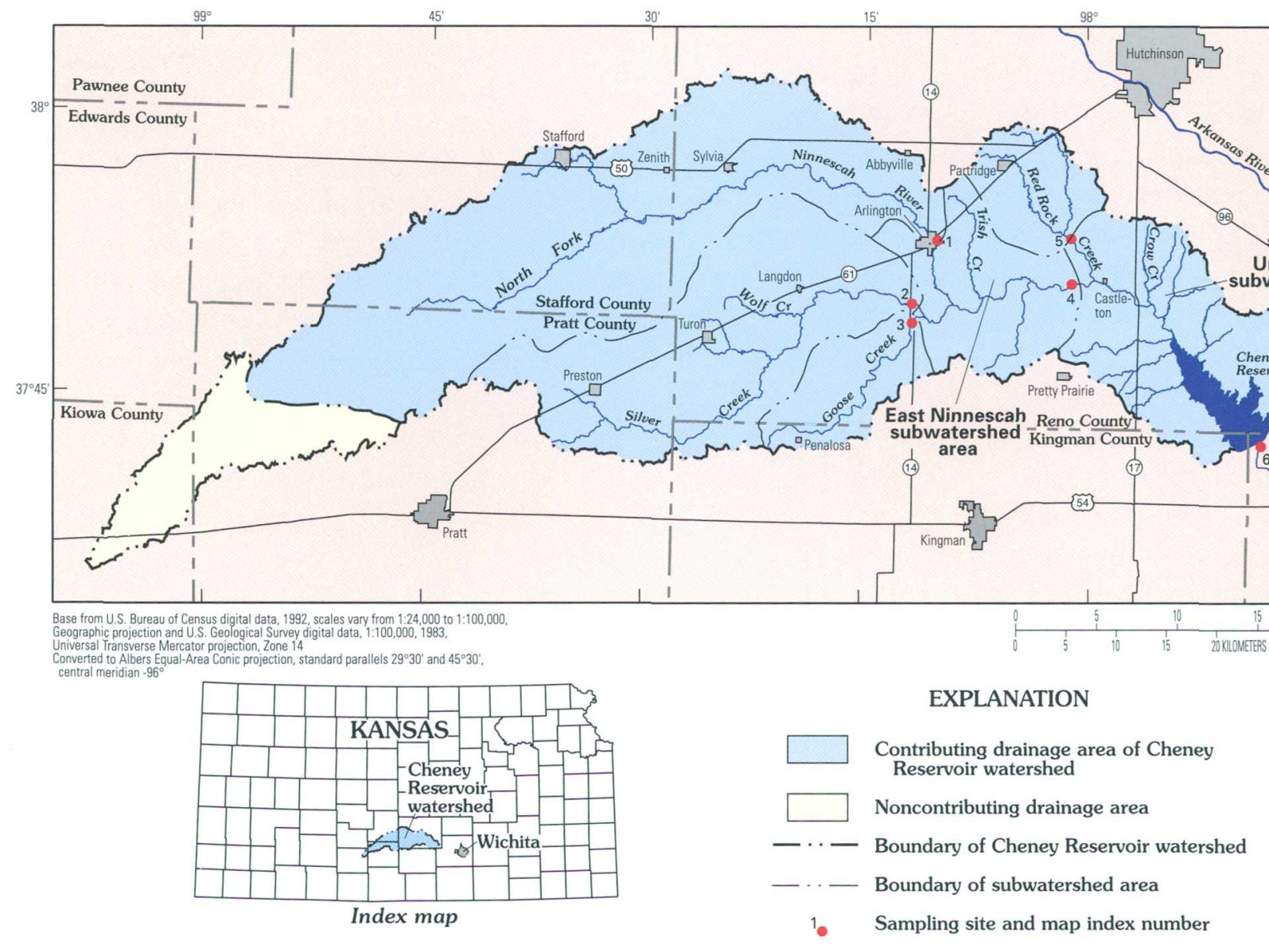

Figure 1. Location of Cheney Reservoir watershed, sampling sites, and subwatershed areas, south-central Kansas. 
Maintaining acceptable surface-water quality in the Cheney Reservoir watershed is important because of its use for domestic and municipal water supplies, irrigation, livestock watering, and recreation. The transport of phosphorous into Cheney Reservoir is a main concern in efforts to maintain a quality water supply. In response to the need for information, the U.S. Geological Survey (USGS), in 1996, entered into a 5-year cooperative study with the city of Wichita, with technical assistance provided by the Bureau of Reclamation. As part of this study, the USGS is to define source areas and quantify mass transport (loads) of phosphorus in the Cheney Reservoir watershed. This information subsequently could be used to assess the effectiveness of implemented watershed management practices in decreasing loads of phosphorus to the reservoir and to identify subwatersheds where additional control measures may be appropriate.

Cheney Reservoir may be affected adversely by phosphorus loading from a predominately agricultural watershed. A previous study of Cheney Reservoir (Pope, 1998) indicated an increasing trend in total phosphorus concentrations associated with reservoir bottom sediment. This trend is probably of nonpointsource origin because of the absence of substantial point-source discharges, and may be related to an increase in fertilizer sales in the area, which more than doubled between 1965 and 1996, and to livestock production in the watershed (Christensen and Pope, 1997).

The purpose of this report is to provide a preliminary assessment of phosphorus transport in the Cheney Reservoir watershed on the basis of the first 2 years (January 1, 1997, through December 31, 1998) of phosphorus data collection at selected sampling sites in the watershed. This assessment examines annual phosphorus loads (mass) and yields (mass per unit area). Results and methods used for this study may have transferability to other watersheds in Kansas or the Nation, especially those with similar land-use and land-management characteristics.

\section{DESCRIPTION OF CHENEY RESERVOIR WATERSHED}

The 933-square-mile (597,000 acres) contributing drainage area of Cheney Reservoir consists of the North Fork Ninnescah River and associated tributary streams that drain a watershed used mainly for crop and livestock production (fig. 2). Since 1965 when Cheney Reservoir was constructed, the percentage of

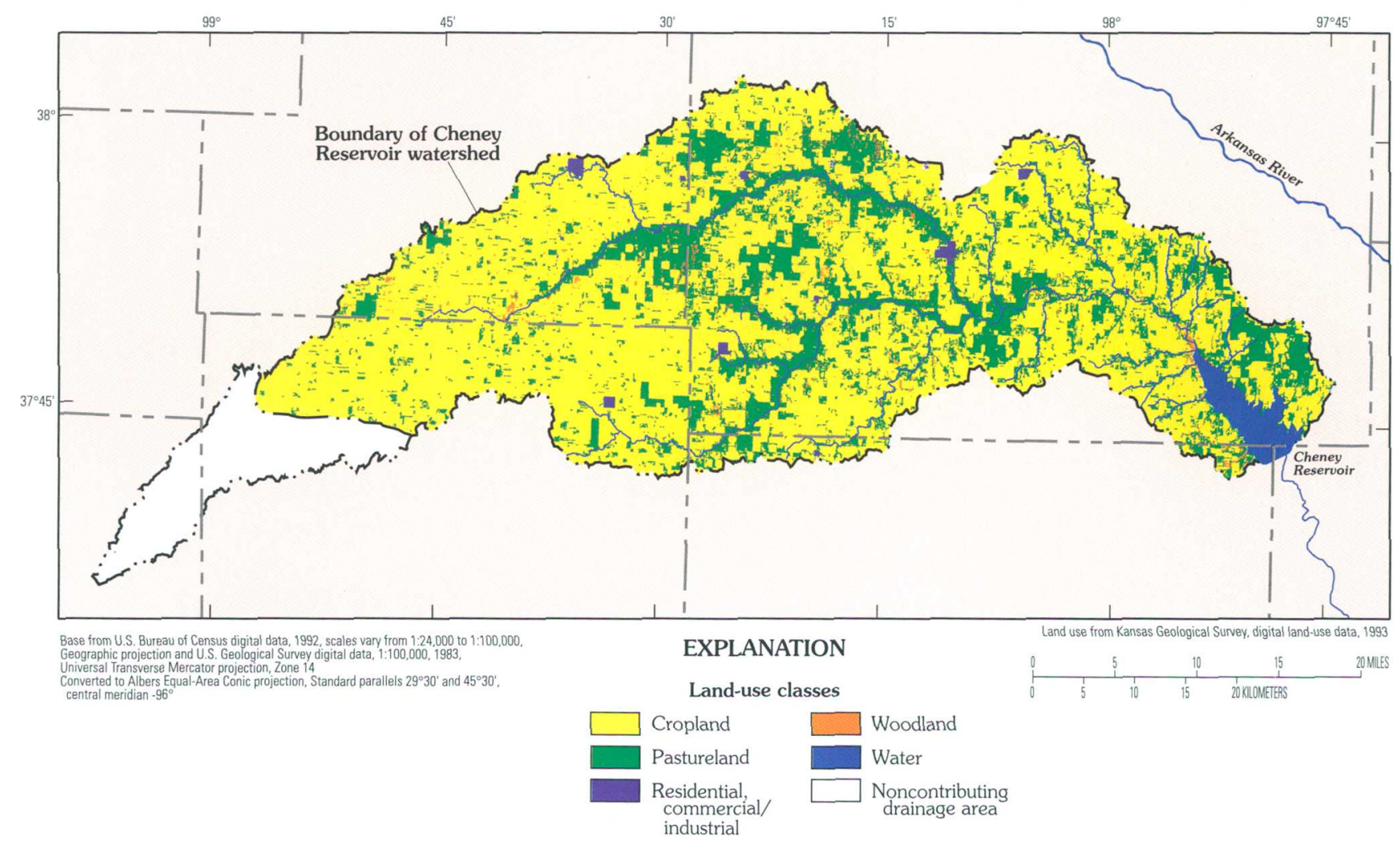

Figure 2. Land use in the Cheney Reservoir watershed, 1993. 


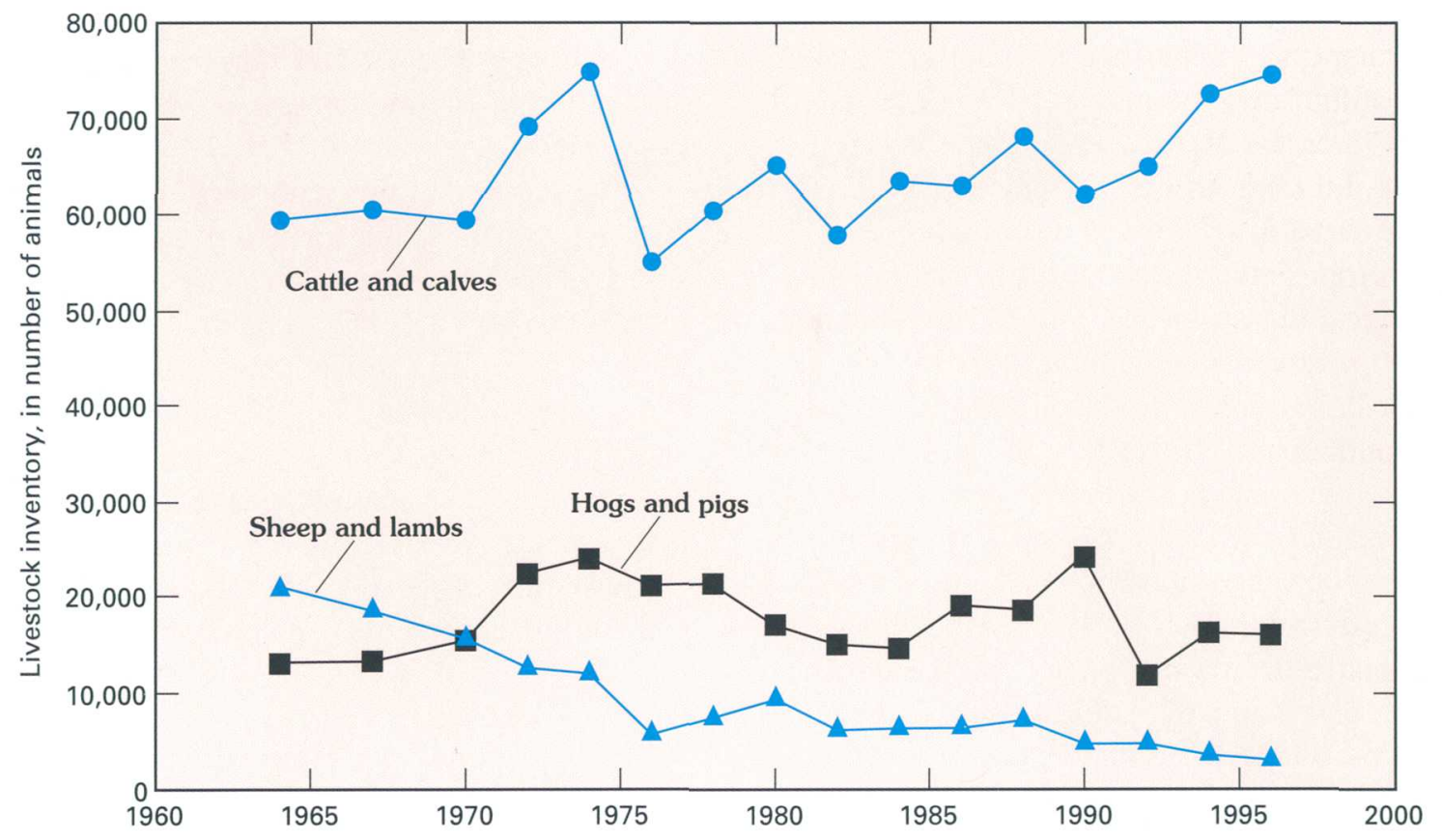

Figure 3. Livestock inventories in the Cheney Reservoir watershed for selected years between 1964 and 1996 (source of data: Kansas State Board of Agriculture, 1964-94; Kansas Department of Agriculture and U.S. Department of Agriculture, 1995-97).

the watershed used for major crop production (corn, sorghum, soybean, and wheat) has averaged about 52 percent annually. Annual inventories of livestock since 1965 have averaged about 64,000 cattle and calves, 18,000 hogs and pigs, and 9,400 sheep and lambs (fig. 3). Crop production and livestock inventories were estimated from county data presented in Kansas State Board of Agriculture and U.S. Department of Agriculture (1964-94) and Kansas Department of Agriculture and U.S. Department of Agriculture (1995-97).

The human population in the Cheney Reservoir watershed is less than 4,000, many of whom are associated with the approximately 1,000 farms in the watershed (Cheney Reservoir Watershed Task Force Committee, written commun., 1996). Populations of the six largest towns in the watershed range from less than 200 to slightly more than 1,200 people (Helyar, 1994).

Annual mean streamflow in the Cheney Reservoir watershed varied considerably between 1997 and 1998 and in comparison to long-term annual means (fig. 4). For example, annual mean streamflow during 1998 at sampling site 4 (fig. 1) was 33 percent larger than that for 1997 and 7 percent larger than the long-term (1965-95) mean annual streamflow at sampling site 4. Similarly, the annual mean discharge from Cheney
Reservoir (sampling site 6) during 1998 was 69 percent larger than that for 1997 and 32 percent larger than the long-term (1965-98) mean annual streamflow at sampling site 6 .

The long-term (1965-95) mean annual streamflow at sampling site 4 was calculated from data collected at a USGS streamflow-gaging station located 4 miles downstream (at Kansas Highway 17, fig. 1). In February 1996, this gaging station was relocated to sampling site 4 . To make comparisons of annual mean streamflow at sampling site 4 for 1997 and 1998 to a longterm mean annual streamflow, it was necessary to adjust the 1997 and 1998 annual means to account for the relocation of the station. The adjustment was made by summing the annual mean streamflows at sampling sites 4 and 5 and an estimate of annual mean streamflow for the approximately 20 -square-mile ungaged area downstream from sampling sites 4 and 5 and upstream from the old gaging-station site at Highway 17. These adjusted annual mean streamflows at sampling site 4 are shown in figure 4.

\section{STUDY METHODS}

A network of six streamflow-gaging/waterquality-sampling sites (fig. 1, table 1) was established in the Cheney Reservoir watershed in the fall of 1996. 
These sites were established to define water-quality characteristics of the North Fork Ninnescah River and selected tributary streams and to evaluate spatial variability in phosphorus transport within the watershed and into and out of Cheney Reservoir (Pope and Christensen, 1997). A continuous record of stream stage (water-surface elevation) was recorded at each site using pressure transducers and electronic datacollection platforms. Daily mean streamflow (in cubic feet per second) was calculated by relating stream stage to stage/streamflow relations using methods presented by Kennedy (1983).

In addition to the six sampling sites shown in figure 1, phosphorus transport data were obtained for two additional areas of the Cheney Reservoir watershed. The East Ninnescah subwatershed area is an 86.2-square-mile drainage area downstream from sampling sites 1-3 and upstream from sampling site 4 . The ungaged subwatershed area is the drainage area downstream from sampling sites 4 and 5 and upstream from Cheney Reservoir. The drainage area of the ungaged subwatershed area is 131 square miles and was calculated by subtracting the sum of the drainage areas for sampling sites 4 and 5 and the conservation-pool surface area of Cheney Reservoir (15 square miles) from the drainage area of sampling site 6. Phosphorus transport data for these two additional areas were determined from differences between phosphorus transport data in upstream and downstream areas (East Ninnescah subwatershed area) or on the basis of phosphorus transport data for adjoining Ninnescah River.

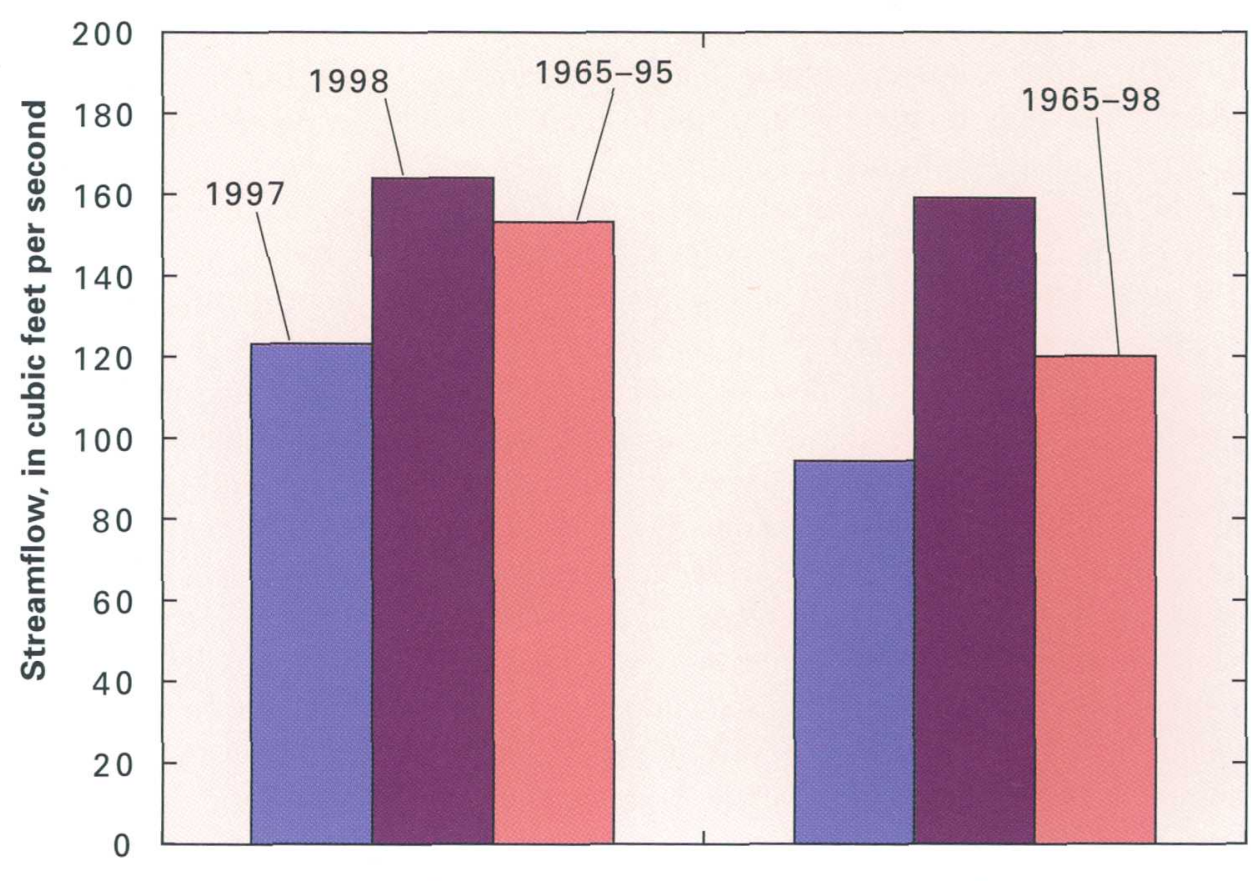

4

6

Sampling site (fig. 1)

Figure 4. Comparison of annual mean streamflow for 1997 and 1998 with long-term (1965-95 or 1965-98) mean annual streamflow at two sampling sites on the North Fork

Table 1. Description of sampling sites in the Cheney Reservoir watershed

\begin{tabular}{|c|c|c|c|}
\hline $\begin{array}{l}\text { Sampling- } \\
\text { site map } \\
\text { index } \\
\text { number } \\
\text { (fig. 1) }\end{array}$ & $\begin{array}{l}\text { U.S. Geological } \\
\text { Survey site } \\
\text { identification } \\
\text { number }\end{array}$ & Sampling-site name & $\begin{array}{c}\text { Contribu- } \\
\text { ting } \\
\text { drainage } \\
\text { area } \\
\text { (square } \\
\text { miles) }\end{array}$ \\
\hline 1 & 07144601 & $\begin{array}{l}\text { North Fork Ninnescah River at Arlington, } \\
\text { Kansas }\end{array}$ & 403 \\
\hline 2 & 07144660 & Silver Creek near Arlington, Kansas & 193 \\
\hline 3 & 07144680 & Goose Creek near Arlington, Kansas & 51.8 \\
\hline 4 & 07144780 & $\begin{array}{l}\text { North Fork Ninnescah River near Pretty } \\
\text { Prairie, Kansas }\end{array}$ & 734 \\
\hline 5 & 07144730 & Red Rock Creek near Pretty Prairie, Kansas & 53.2 \\
\hline 6 & 07144795 & $\begin{array}{l}\text { North Fork Ninnescah River at Cheney Dam, } \\
\text { Kansas }\end{array}$ & 933 \\
\hline
\end{tabular}

areas (ungaged subwatershed area). These two additional areas were included in the analysis to provide estimates of total annual phosphorus transport to Cheney Reservoir and to improve characterization of source areas of phosphorus.

Samples of streamflow for determination of total phosphorus concentrations were collected either 
manually (manual samples) (Horowitz and others, 1994) or with automatic samplers (automatic samples). Automatic samplers were installed at all sampling sites upstream from Cheney Reservoir (sites 1-5, fig. 1). All samples collected at sampling site 6 (outflow of Cheney Reservoir) were collected manually. The automatic samplers used during this study were capable of collecting four 1-gallon samples before service was required. All low-flow and some runoff samples were collected manually. Most runoff samples were collected with automatic samplers. Manual samples were collected to provide a depth- and widthintegrated composite sample representative of the chemical composition of the stream's average crosssectional area. Automatic samples were collected from a single point in the stream cross-sectional area and, therefore, may not be representative of the chemical composition of the stream's average cross-sectional area at the time of sample collection.

Samples were analyzed for total phosphorus concentrations at the city of Wichita laboratory using U.S. Environmental Protection Agency method 365.2. The results of analyses of these manual and automatic samples are listed in table 4 in the "Supplemental Information" section of this report.

Concentrations of total phosphorus determined from automatically collected point samples were adjusted to approximate the average cross-sectional phosphorus concentration provided by depth- and width-integrated manually collected samples. This approximation was accomplished through the development and application of a linear-regression relation (fig. 5) between total phosphorus concentrations determined for pairs of concurrently collected manual and automatic samples from sampling sites 1-5 (fig. 1), as described below.

Variation in site-specific installation characteristics of automatic samplers and the relation of the sampler intake to stream geomorphic and hydrologic characteristics may indicate that a unique relation between total phosphorus concentrations in manual and automatic samples exists at each sampling site; however, the 1997-98 data are insufficient to define individual sampling-site relations if they do exist. Therefore, for the purpose of this preliminary assessment of phosphorus transport, data from all sampling sites with automatic samplers were grouped to develop a single regression relation that was used to adjust total phosphorus concentrations in automatically collected samples from sampling sites $1-5$. The equation for this regression relation produced an adjustment coefficient (slope of the regression line) of 0.854 that was applied to all total phosphorus concentrations determined in automatically collected samples. The regression relation was forced through the graphical origin (fig. 5) to validate the assumption that a zero concentration in a manually collected sample would equate to a zero concentration in an automatically collected sample.

Annual phosphorus loads for 1997 and 1998 at sampling sites 1-5 (fig. 1) were estimated by sitespecific regression equations relating phosphorus load (dependent variable) to streamflow (independent variable). Phosphorus loads (in grams per second) for use in regression analysis were calculated by multiplying total phosphorus concentrations from manual samples and adjusted total phosphorus concentrations from automatic samples by streamflow (in cubic feet per second) by a unit conversion factor (0.02832).

Regression analysis was conducted on logarithms of phosphorus loads and streamflow and produced log$\log$ model estimation equations. The log-log equations were retransformed to exponential form (table 2) to estimate phosphorus loads in original units of measurement (grams per second). Because the residuals for the exponential form of the log-log model are approximately log normally distributed, the exponential form estimates the median value of the retransformed dependent variable but gives biased (low) estimates of the mean (Martin and Crawford, 1987). A smearing method developed by Duan (1983) was used to correct the bias of the exponential form of the loglog model. The bias correctors (table 2) were multiplied by the estimates of the median obtained from the estimation equations.

Daily mean streamflow from sampling sites $1-5$ was used as the input (independent) variable for the equations in table 2 to estimate daily mean phosphorus loads (in grams per second). Daily phosphorus loads (in grams) were calculated by multiplying the daily mean load by the bias corrector by the number of seconds in a day $(86,400)$. Daily phosphorus loads at sampling site 6 (fig. 1), the outflow of Cheney Reservoir, were calculated by multiplying daily mean total phosphorus concentrations by streamflow by a unit conversion factor by the number of seconds in a day. Daily mean total phosphorus concentrations at sampling site 6 were estimated from frequently collected samples with linear interpolation for those days between sample collections. This method was 


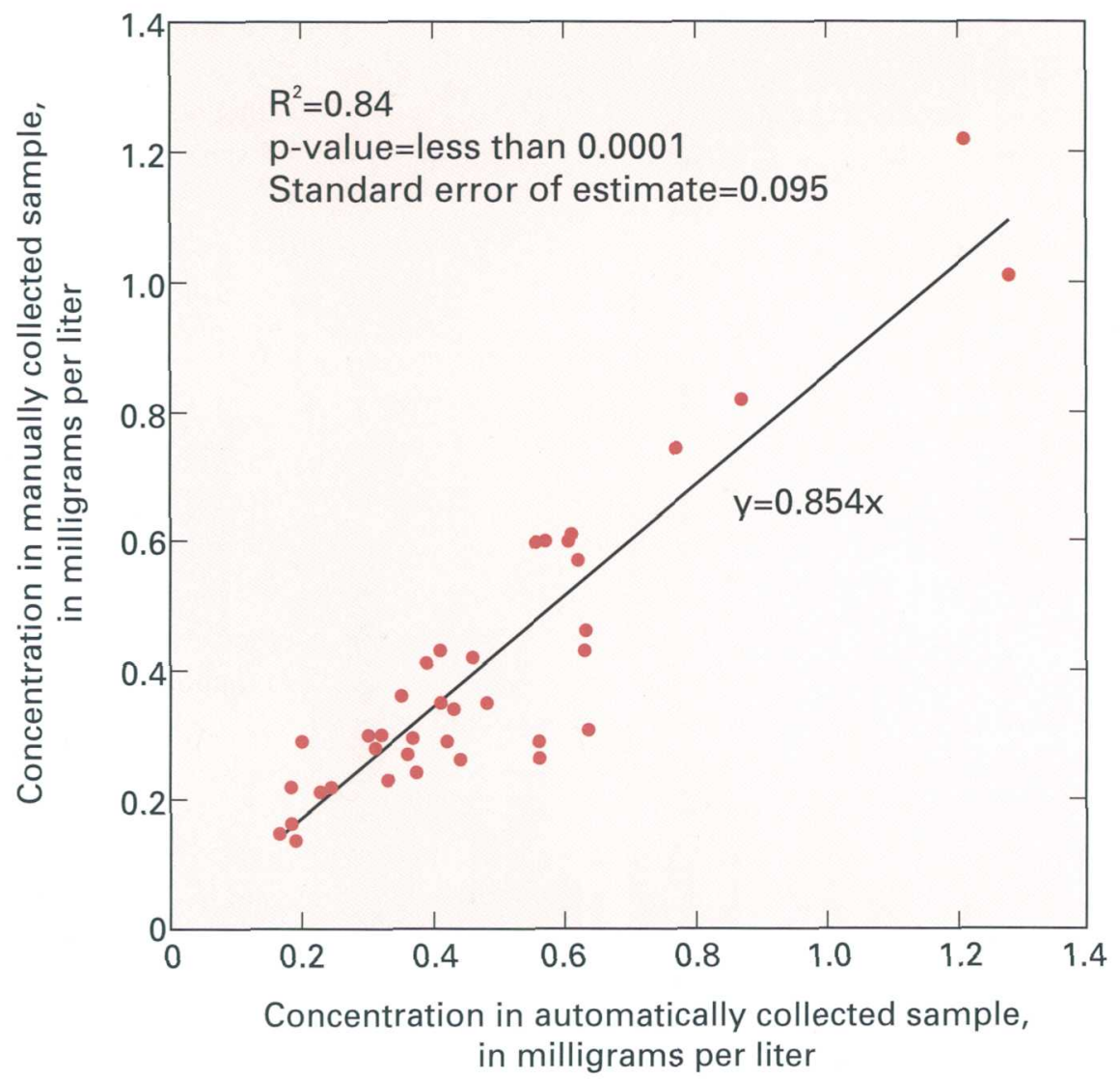

Figure 5. Relation between phosphorus concentrations determined for manually and automatically collected concurrent samples at sampling sites 1-5 in the Cheney Reservoir watershed, 1997-98. adequate because of the lack of variability, for a given time, in total phosphorus concentrations relative to streamflow (reservoir discharge).

Annual loads of phosphorus (in pounds) for 1997-98 at all sampling sites were calculated by summing the daily loads (in grams) for each year and multiplying by a unit conversion factor (0.00220).

Annual yields of phosphorus (in pounds per acre) were calculated by dividing the annual loads by the drainage area (in acres) for each sampling site.

\section{PHOSPHORUS TRANSPORT}

Estimates of phosphorus loads transported in streamflow at sampling sites 1-6 and for two additional subwatershed areas (East Ninnescah subwatershed area and ungaged subwatershed area) varied substantially between 1997 and 1998 (fig. 6, table 3). Estimated

Table 2. Results of regression analysis relating streamflow and phosphorus loads at five sampling sites upstream from Cheney Reservoir

[PL, total phosphorus load, in grams per second; Q, streamflow, in cubic feet per second; $\mathrm{r}$, residual of log-log regression model; g/s, grams per second; $\mathrm{ft}^{3} / \mathrm{s}$, cubic feet per second. All estimation equations are significant at a p-value of less than 0.0001]

\begin{tabular}{|c|c|c|c|c|c|c|c|}
\hline $\begin{array}{l}\text { Sampling- } \\
\text { site map } \\
\text { index } \\
\text { number } \\
\text { (fig. 1) }\end{array}$ & Estimation equation & $\begin{array}{c}\text { Bias } \\
\text { corrector }^{1} \\
{\left[\left(\Sigma 10^{r}\right) / \mathrm{n}\right]}\end{array}$ & $\begin{array}{l}\text { Number of } \\
\text { data pairs } \\
\text { used in } \\
\text { analysis } \\
\text { (n) }\end{array}$ & $\begin{array}{l}\text { Coefficient of } \\
\text { determination } \\
\qquad\left(R^{2}\right)\end{array}$ & $\begin{array}{l}\text { Standard } \\
\text { error of } \\
\text { regression } \\
\left(\log _{10}\right. \\
\mathrm{g} / \mathrm{s})\end{array}$ & $\begin{array}{c}\text { Range of } \\
\text { streamflow used } \\
\text { to develop } \\
\text { equations } \\
\left(\mathrm{ft}^{3} / \mathrm{s}\right)\end{array}$ & $\begin{array}{c}\text { Range of daily } \\
\text { mean streamflow } \\
\text { used in } \\
\text { estimation } \\
\text { equations } \\
\left(\mathrm{ft}^{3} / \mathrm{s}\right)\end{array}$ \\
\hline 1 & $\mathrm{PL}=0.00065\left(\mathrm{Q}^{1.533}\right)$ & 1.19 & 93 & 0.79 & 0.264 & $15-513$ & $13.0-507$ \\
\hline 2 & $\mathrm{PL}=0.00335\left(\mathrm{Q}^{1.141}\right)$ & 1.21 & 70 & .89 & .278 & $.1-573$ & $.01-560$ \\
\hline 3 & $\mathrm{PL}=0.00250\left(\mathrm{Q}^{1.363}\right)$ & 1.25 & 65 & .93 & .274 & $.08-469$ & $.03-408$ \\
\hline 4 & $\mathrm{PL}=0.00066\left(\mathrm{Q}^{1.428}\right)$ & 1.30 & 79 & .81 & .321 & $12-2,260$ & $11.0-1,920$ \\
\hline 5 & $\mathrm{PL}=0.00389\left(\mathrm{Q}^{1.301}\right)$ & 1.14 & 99 & .94 & .271 & $.42-1,040$ & $.27-1,100$ \\
\hline
\end{tabular}

\footnotetext{
${ }^{1}$ Duan (1983).
} 


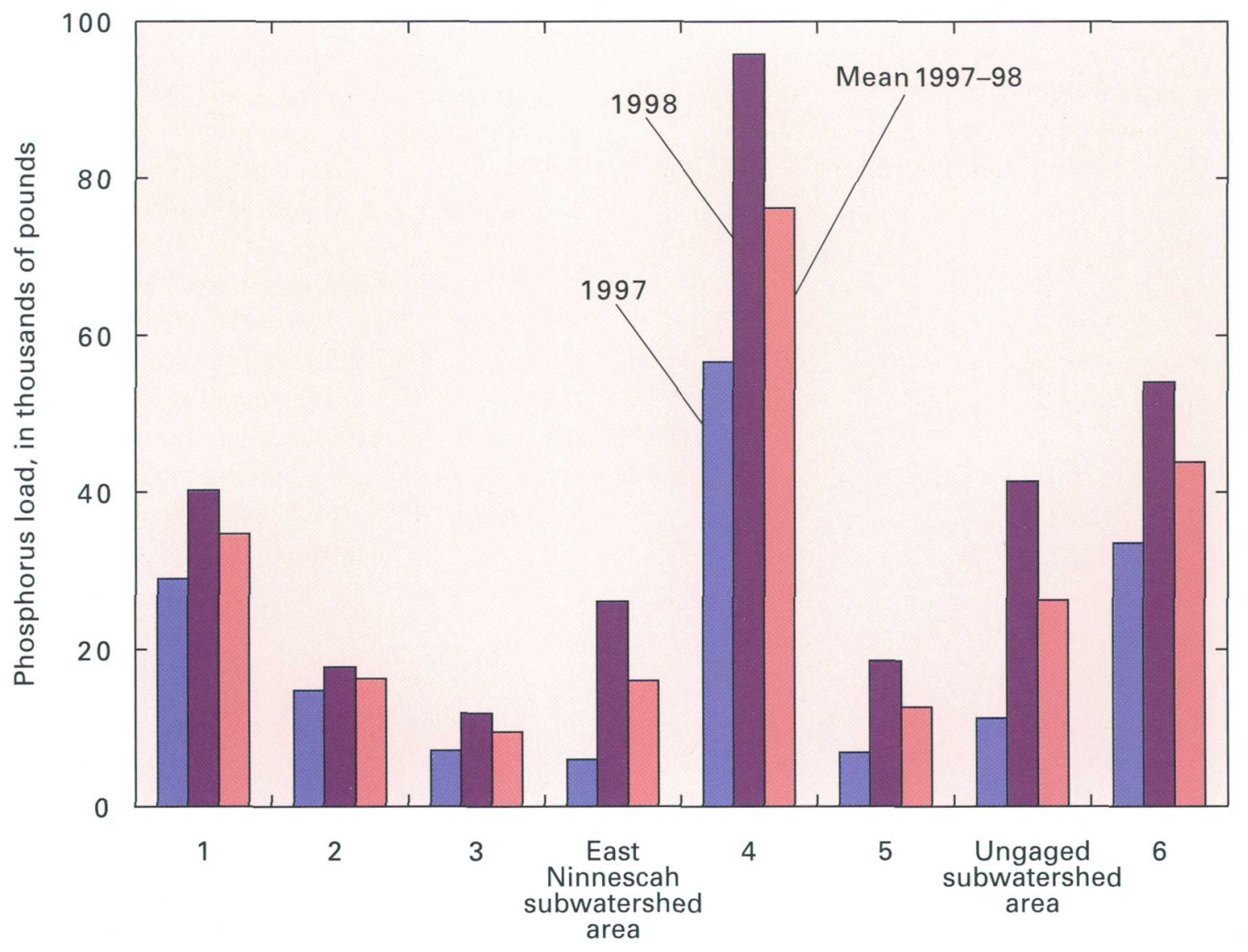

Sampling site or subwatershed area (fig. 1)

Figure 6. Comparison of 1997 and 1998 annual loads of phosphorus estimated for selected sampling sites or subwatershed areas in the Cheney Reservoir watershed.

Table 3. Estimated loads and yields of phosphorus transported in streamflow at selected sampling sites and for subwatershed areas in the Cheney Reservoir watershed, 1997-98

[lb, pounds; lb/acre, pounds per acre]

\begin{tabular}{|c|c|c|c|c|c|c|c|}
\hline \multirow{2}{*}{$\begin{array}{l}\text { Sampling-site map index } \\
\text { number or subwatershed } \\
\text { area(fig. } 1 \text { ) }\end{array}$} & \multirow{2}{*}{$\begin{array}{c}\text { Contributing } \\
\text { drainage area } \\
\text { (acre) }\end{array}$} & \multicolumn{2}{|c|}{1997} & \multicolumn{2}{|c|}{1998} & \multicolumn{2}{|c|}{ Mean 1997-98 } \\
\hline & & $\begin{array}{l}\text { Load } \\
\text { (lb) }\end{array}$ & $\begin{array}{c}\text { Yield } \\
\text { (lb/acre) }\end{array}$ & $\begin{array}{l}\text { Load } \\
\text { (lb) }\end{array}$ & $\begin{array}{c}\text { Yield } \\
\text { (lb/acre) }\end{array}$ & $\begin{array}{l}\text { Load } \\
\text { (lb) }\end{array}$ & $\begin{array}{c}\text { Yield } \\
\text { (Ib/acre) }\end{array}$ \\
\hline 1 & 258,000 & 28,900 & 0.112 & 40,200 & 0.156 & 34,600 & 0.134 \\
\hline 2 & 124,000 & 14,700 & .119 & 17,700 & .143 & 16,200 & .131 \\
\hline 3 & 33,200 & 7,040 & .212 & 11,800 & .355 & 9,420 & .284 \\
\hline East Ninnescah & 54,800 & 5,860 & .107 & 26,000 & .474 & 15,900 & .290 \\
\hline subwatershed area ${ }^{1}$ & & & & & & & \\
\hline 4 & 470,000 & 56,500 & .120 & 95,700 & .204 & 76,100 & .162 \\
\hline 5 & 34,000 & 6,770 & .199 & 18,500 & .544 & 12,600 & .371 \\
\hline $\begin{array}{l}\text { Ungaged } \\
\text { subwatershed area }{ }^{2}\end{array}$ & 83,800 & 11,200 & .134 & 41,300 & .493 & 26,200 & .313 \\
\hline 6 & 597,000 & 33,400 & .056 & 54,000 & .090 & 43,700 & .073 \\
\hline
\end{tabular}
site 4.

${ }^{1}$ Loads estimated by subtracting the sum of the loads determined at sampling sites $1-3$ from the loads determined at sampling

${ }^{2}$ Load and yield estimates were calculated from yields available for the East Ninnescah subwatershed area and sampling site 5. Ratios of 0.70 and 0.30 , on the basis of relative drainage areas, were applied to those respective yield values in determining yields for the ungaged subwatershed area. Annual loads were calculated by multiplying yield by drainage area. 
phosphorus loads at all sampling sites and subwatershed areas were substantially larger in 1998 than in 1997. The median percentage increase between 1997 and 1998 at these locations was 68 percent. This increase is due, in large part, to greater streamflow in the watershed in 1998 (fig. 4). Among the sampling sites and subwatershed areas, estimated phosphorus loads ranged from 5,860 pounds (East Ninnescah subwatershed area) to 56,500 pounds (sampling site 4 ) in 1997 and from 11,800 pounds (sampling site 3 ) to 95,700 pounds (sampling site 4) in 1998.

Estimated phosphorus loads transported from Cheney Reservoir (sampling site 6, fig. 6) included estimated loads in water withdrawn as municipal supply by the city of Wichita. The amount of water annually used by the city is substantial. For 1997-98, a mean annual volume of 131,000 acre-feet was removed (discharged or withdrawn) from Cheney Reservoir. Of this amount, 30 percent was withdrawn as municipal supply (Joan F. Kenny, U.S. Geological Survey, written commun., 1999). Therefore, annual total phosphorus transport from the reservoir is a summation of that determined in discharge at sampling site 6 and that associated with municipal-supply withdrawal. Phosphorus loads in municipal supply were estimated by multiplying the volume (in acre-feet) of water withdrawn for municipal supply by the mass per unit volume (in pounds per acre-feet) determined in discharge water at sampling site 6 . The underlying assumption in this estimation method is that total phosphorus concentrations in the discharge and withdrawal water are similar. Because of the close proximity of the reservoir discharge point and municipalsupply intakes and the fact that the reservoir is not known to thermally, and hence, chemically stratify, this assumption is believed to be valid.

The calculation of phosphorus loads is largely dependent on streamflow values used as independent variables in the estimation equations (table 2). Because streamflow is directly (positively) related to drainage area, it was expected that sampling sites with the largest drainage areas would have the largest phosphorus loads which, indeed, is evident upon comparison of figure 6 with figure 4 and table 1 . The relation between streamflow and drainage area, however, makes a site-to-site evaluation of loads rather meaningless. A more useful approach is to normalize annual loads with respect to drainage area (loads divided by drainage area). The resulting annual phosphorus yields then can be used to make direct site-to-site comparisons.

Estimated phosphorus yields in the Cheney Reservoir watershed (upstream from sampling site 6) for 1997-98 varied substantially among sampling sites and subwatershed areas (fig. 7, table 3 ). The smallest mean annual phosphorus yields of those sampling sites or subwatershed areas upstream from Cheney Reservoir were estimated for sampling sites 1 and 2 in the western part of the watershed. Both of these sampling sites had mean annual phosphorus yields of about 0.13 pound per acre (table 3 ). In contrast, mean annual phosphorus yields estimated for the other sampling sites or for the two subwatershed areas ranged from 1.2 (sampling site 4) to 2.8 (sampling site 5) times larger than the yields estimated for sampling sites 1 and 2. Thus, some areas of the Cheney Reservoir watershed have much greater yield potential than others.

Estimated mean annual (1997-98) phosphorus yields from subwatersheds of the Cheney Reservoir watershed generally increased in an easterly direction (fig. 8). This condition probably relates to a combination of factors, not the least of which is mean annual (1997-98) water yield (combination of base flow and storm runoff) from these subwatersheds. Mean annual water yield ranged from 108 acre-feet per square mile at sampling site 1 to 198 acre-feet per square mile for the East Ninnescah subwatershed area (fig. 9). Generally, subwatersheds with the largest mean water yield also had the largest phosphorus yields (fig. 7).

Differences in mean annual water yield probably are related to differences in precipitation, soil characteristics, and topography among the subwatersheds. Precipitation generally increased in an easterly direction in the Cheney Reservoir watershed. Long-term (1961-90) annual mean precipitation varied from 25.84 inches at Pratt (fig. 1) to 29.22 inches at Hutchinson (National Oceanic and Atmospheric Administration, 1992). Soils in the western part of the Cheney Reservoir watershed tend to be sandier, with greater rainfall infiltration capacity (Horsch and others, 1968; Dodge and others, 1978), than the more sandy to clayey loam soils that are more prevalent in the eastern part of the watershed (Rockers and others, 1966). The greater rainfall infiltration capacity in the western part of the watershed would mitigate storm runoff in that area relative to the eastern part of the watershed. Topography (local relief) also tends to increase in an easterly direction within the watershed 


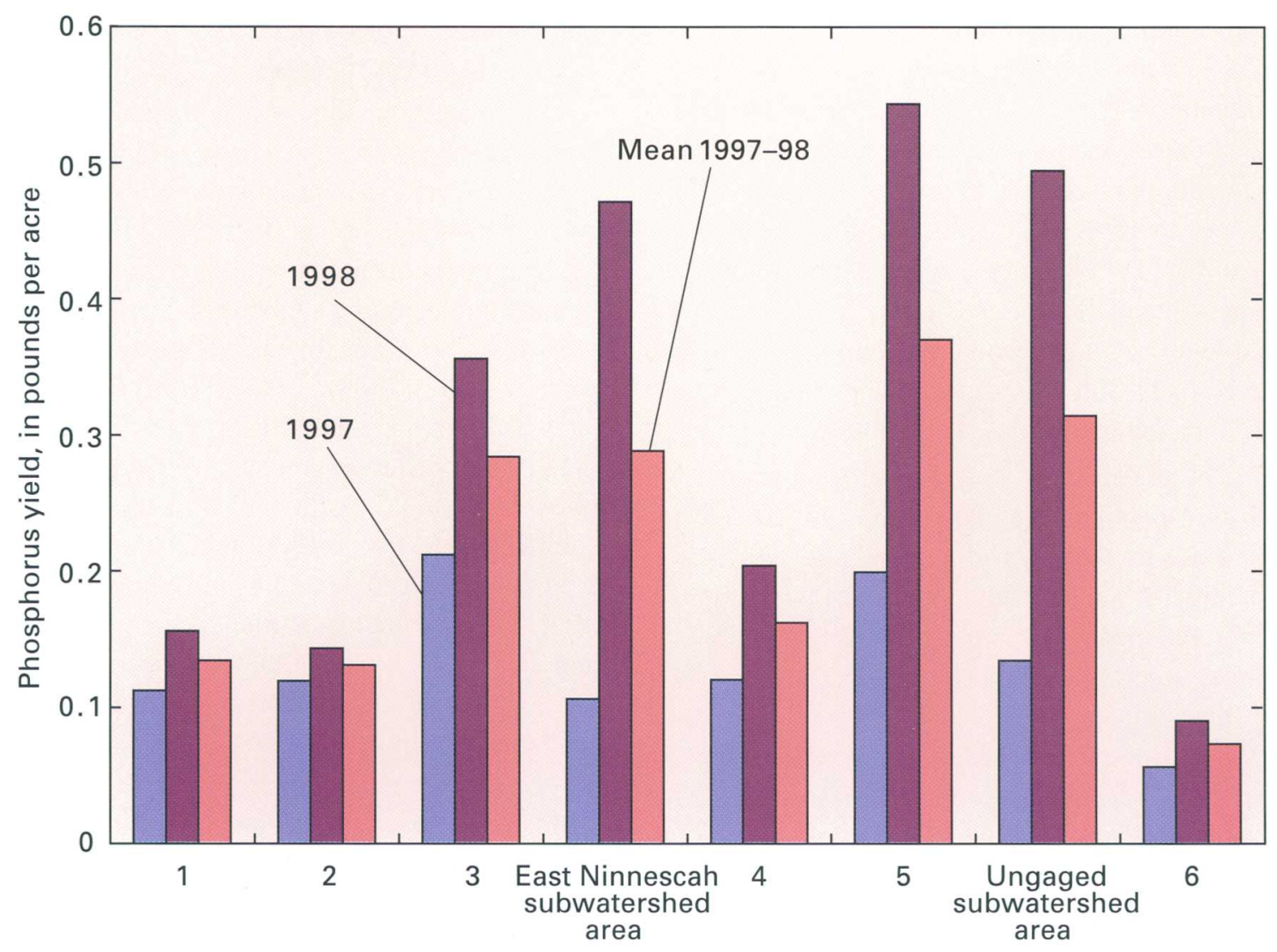

Sampling site or subwatershed area (fig. 1)

Figure 7. Comparison of 1997 and 1998 annual phosphorus yields estimated for selected sampling sites or subwatershed areas in the Cheney Reservoir watershed.

that could, because of greater land slopes, increase runoff potential in the eastern subwatersheds. Additional factors affecting water yield may include landuse and land-management characteristics.

Estimated total annual phosphorus load transported into Cheney Reservoir by its tributary streams (inflow) in 1998 (156,000 pounds) was more than twice the estimated load transported in 1997 (74,500 pounds) (fig. 10). Total annual phosphorus loads were calculated by adding the annual loads at sampling sites 4 and 5 and the ungaged subwatershed area (table 3). This difference between years is reflective of similar differences between years at all sampling sites within the watershed and is related to variations in hydrologic conditions between the 2 years (fig. 4). In contrast, estimated annual phosphorus outflow loads were substantially less than inflow loads, which indicates that a large part of the phosphorus load transported into Cheney Reservoir is retained within the reservoir and is associated with bottom sediment (Pope, 1998). On average (1997-98), Cheney
Reservoir has a phosphorus retention efficiency of about 62 percent.

Estimated total annual phosphorus yields for the entire Cheney Reservoir watershed ranged from 0.13 pound per acre in 1997 to 0.27 pound per acre in 1998 (a mean annual yield of 0.20 pound per acre for 1997-98). Annual phosphorus yields were calculated by dividing total annual phosphorus loads (sum of loads for sampling sites 4 and 5 and the ungaged subwatershed area) by the watershed drainage area $(597,000$ acres $)$ minus the surface area of the reservoir (9,600 acres).

\section{COMPARISON OF PRELIMINARY RESULTS WITH PREVIOUS STUDIES IN KANSAS}

The significance of the mean annual phosphorus yield estimate of 0.20 pound per acre for 1997-98 may be placed in perspective when compared to estimated 


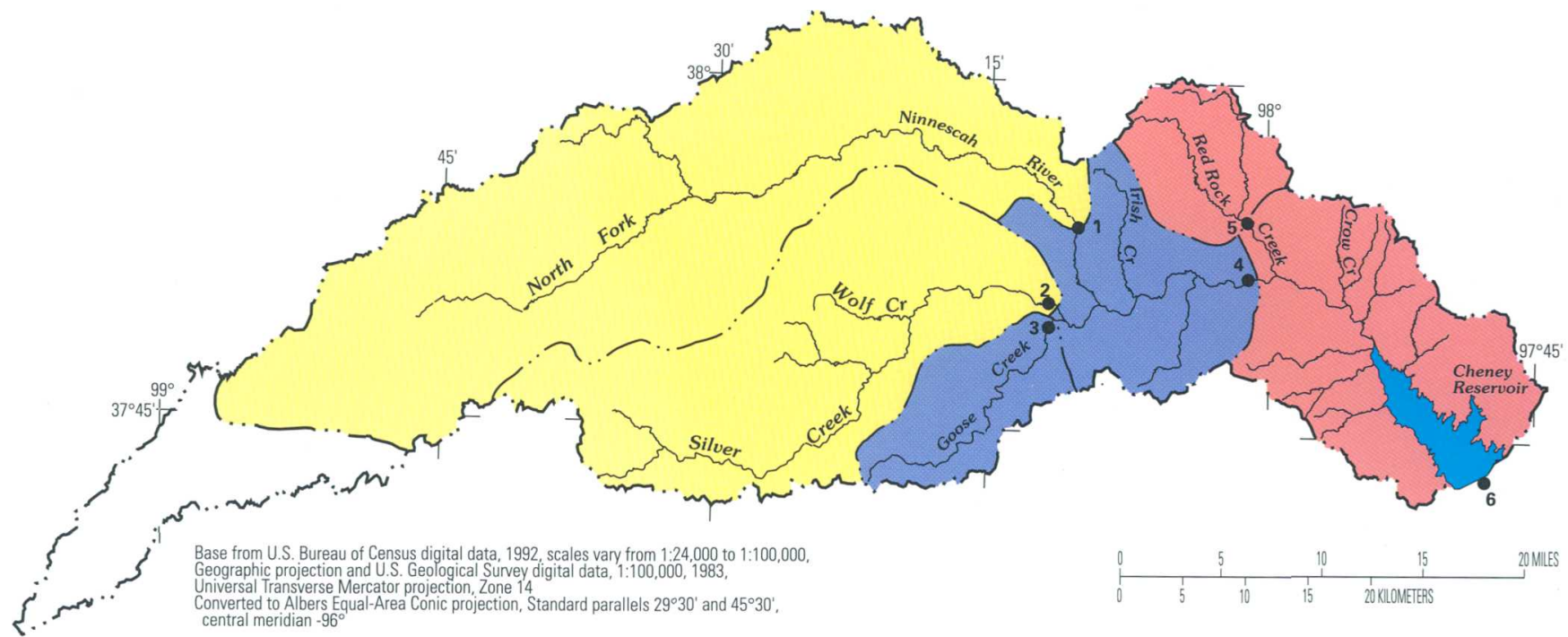

EXPLANATION

Mean annual phosphorus yields, in pounds per acre

$0.10-0.20$

- - - Boundary of Cheney Reservoir watershed

$0.21-0.30$

-..- Subwatershed boundary

$0.31-0.40$

1. Sampling site and map index number

\section{Noncontributing drainage area}

Figure 8. Distribution of mean annual phosphorus yields estimated for the Cheney Reservoir watershed, 1997-98.

yields from watersheds of other reservoirs. The mean annual (1985-96) phosphorus yield from the watershed of Hillsdale Lake, a reservoir in northeast Kansas, was estimated at 1.76 pounds per acre on the basis of an analysis of phosphorus associated with reservoir bottom sediment (Juracek, 1997). Many factors are responsible for this much larger phosphorus yield from the Hillsdale Lake watershed. One of the more significant, undoubtedly, is annual water yield in the Hillsdale Lake watershed, which, for 1997-98, was five to seven times larger than in the Cheney Reservoir watershed (Putnam and others, 1998-99). Additional factors may include differences in soil composition and structure, topography, phosphorus use and distribution, and occurrence of substantial point-source discharges of phosphorus in the Hillsdale

Lake watershed.

In contrast to the relatively large phosphorus yield from the Hillsdale Lake watershed, the mean annual
(1956-98) phosphorus yield from the Webster Reservoir watershed, north-central Kansas, was estimated at 0.05 pound per acre (Victoria G. Christensen, U.S. Geological Survey, written commun., 1999), only 25 percent of that estimated for the 1997-98 mean annual yield from the Cheney Reservoir watershed. This estimate was determined from recent (1998) data pertaining to bottom sediment in Webster Reservoir. A reason for the small mean annual phosphorus yield from the Webster Reservoir watershed is the relatively small water yield from that watershed (36 acre-feet per square mile in 1997 and 30 acre-feet per square mile in 1998) (Putnam and others, 1998-99).

\section{CONCLUSIONS}

Estimated phosphorus loads and yields at sampling sites and subwatershed areas examined during the 2 years (1997-98) of this preliminary assessment 
of the Cheney Reservoir watershed varied substantially between years. Estimated phosphorus loads were substantially larger in 1998 than in 1997 , with a median increase of 68 percent. This increase was mostly the result of wetter conditions in 1998. Estimated mean annual phosphorus yields for 1997-98 (upstream from Cheney Reservoir) ranged from 0.131 to 0.371 pound per acre. Much of the between-site variability in yields was attributed to variability in water yield and does not represent substantial changes in land-use or landmanagement practices. On average, about 62 percent of the phosphorus load to the reservoir was retained in the reservoir.

Because of the relatively short time span of this assessment, it is believed that annual variation is the result of wetter conditions in 1998 and does not represent substantial changes in land-use or land-management practices. On a year-to-year basis, the subtle variation in phosphorus transport produced by small changes, relative to the size of the watershed, in land-use or landmanagement practices would be obscured by large yearly fluctuations that normally occur in hydrologic conditions within the watershed. The reasons for differences between phosphorus yields among sampling sites and subwatershed areas is not definitively known but probably is a combination of many factors that may include variations in (1) naturally occurring phosphorus; (2) precipitation; (3) soil types and characteristics such as particle size, porosity, and erodibility; (4) topography; and (5) agricultural activities that include the widespread use of phosphorus-containing fertilizers or livestock production (pastured and confined) and resulting distribution of manure.

A mean annual phosphorus yield for 1997-98 for the entire Cheney Reservoir watershed was estimated at 0.20 pound per acre. This compares to mean annual phosphorus yields of 1.76 and 0.05 pounds per acre reported in previous reservoir watershed assessments conducted in the Hillsdale Lake watershed in eastern Kansas in 1996 and the Webster Reservoir watershed in western Kansas in 1998, respectively. Although the estimated mean annual phosphorus yield in the Cheney Reservoir watershed for 1997-98 was 0.20 pound per acre, there is a level of uncertainty with this estimate. This uncertainty arises from little knowledge of phosphorus transport during extreme conditions (major floods) and the degree to which these conditions contribute to the total historical load of phosphorus to Cheney Reservoir. No major floods occurred in the Cheney Reservoir watershed in 1997 or 1998.

Phosphorus loading into Cheney Reservoir undoubtedly is not distributed uniformly through time but probably is skewed toward extreme conditions. This skewness produces the uncertainty of how representative the "snapshot" picture of phosphorus loads and yields estimated for 1997-98 are of the long-term mean annual loads and yields, which could be calculated from the total mass of phosphorus historically 


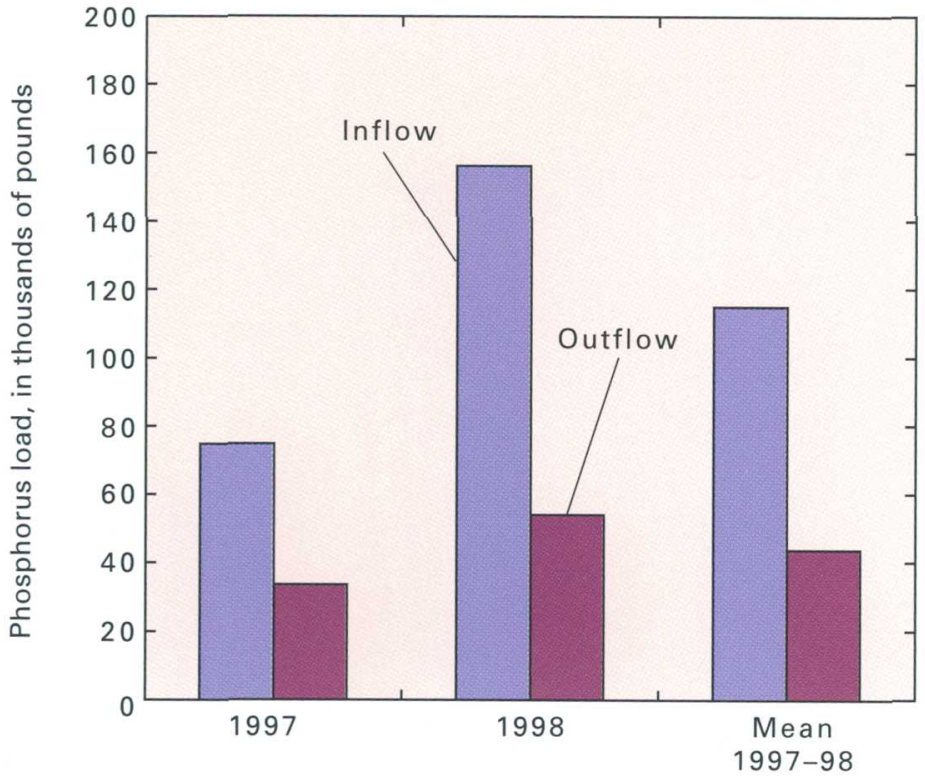

Figure 10. Comparison of 1997 and 1998 estimated annual phosphorus inflow and outflow loads for Cheney Reservoir.

transported into Cheney Reservoir if that mass could be determined.

One method that could be used to estimate historical mass would be an evaluation of sediment deposition and analysis of associated phosphorus within the reservoir. Such an evaluation, made on the basis of a network of sediment core samples, would provide estimates of historical phosphorus transport into Cheney Reservoir and allow for calculation of long-term mean annual phosphorus loads and yields. Results obtained from the current (1997-98) watershed assessment effort then could be evaluated in relation to the longterm means.

\section{REFERENCES}

Christensen, V.G., and Pope, L.M., 1997, Occurrence of dissolved solids, nutrients, atrazine, and fecal coliform bacteria during low flow in the Cheney Reservoir watershed, south-central Kansas, 1996: U.S. Geological Survey Water-Resources Investigations Report 97-4153, 13 p.

Dodge, D.A., Hoffman, B.R., and Horsch, M.L., 1978, Soil survey of Stafford County, Kansas: U.S. Soil Conservation Service, $59 \mathrm{p}$.

Duan, Naihua, 1983, Smearing estimate-a nonparametric retransformation method: Journal of the American Statistical Association, v. 78, no. 383, p. 605-610.

Helyar, Thelma, ed., 1994, Kansas statistical abstract 1992-93: Lawrence, University of Kansas Institute for Public Policy and Business Research, 420 p.
Hem, J.D., 1985, Study and interpretation of chemical characteristics of natural water (3rd ed.): U.S. Geological Survey Water-Supply Paper 2254, 263 p.

Horowitz, A.J., Demas, C.R., Fitzgerald, K.K., Miller, T.L., and Rickert, D.A., 1994, U.S. Geological Survey protocol for the collection and processing of surface-water samples for the subsequent determination of inorganic constituents in filtered water: U.S. Geological Survey Open-File Report 94-539, $57 \mathrm{p}$.

Horsch, M.L., Hoffman, B.R., and Gier, D.A., 1968, Soil survey of Pratt County, Kansas: U.S. Soil Conservation Service, 56 p.

Juracek, K.E., 1997, Analysis of bottom sediment to estimate nonpoint-source phosphorus loads for 1981-96 in Hillsdale Lake, northeast Kansas: U.S. Geological Survey Water-Resources Investigations Report 97-4235, 55 p.

Kansas Department of Agriculture and U.S. Department of Agriculture, 1995-97, Kansas farm facts:

Topeka, Kansas, published annually.

Kansas State Board of Agriculture and U.S. Department of Agriculture, 1964-94, Kansas farm facts:

Topeka, Kansas, published annually.

Kennedy, E.J., 1983, Computation of continuous records of streamflow: U.S. Geological Survey Techniques of Water-Resources Investigations, book 3, chap. A13, $53 \mathrm{p}$.

Martin, J.D., and Crawford, C.G., 1987, Statistical analysis of surface-water-quality data in and near the coal-mining region of southwestern Indiana, 1957-80: U.S. Geological Survey Water-Supply Paper 2291, 92 p.

National Oceanic and Atmospheric Adminstration, 1992, Monthly station normals of temperature, precipitation, and heating and cooling degree days, 1961-90, Kansas: Asheville, N.C., National Climatic Center, 36 p.

Pope, L.M., 1998, Watershed trend analysis and water-quality assessment using bottom-sediment cores from Cheney Reservoir, south-central Kansas: U.S. Geological Survey Water-Resources Investigations Report 98-4227, 24 p.

Pope, L.M., and Christensen, V.G., 1997, Water-quality study of the Cheney Reservoir watershed, south-central Kansas: U.S. Geological Survey Fact Sheet FS-14-97, 2 p.

Putnam, J.E., Lacock, D.L., Schneider, D.R., and Carlson, M.D., 1998-99, Water resources data, Kansas, 1997-98: U.S. Geological Survey Water-Data Reports KS-97-1 and KS-98-1, published annually.

Reid, G.K., and Wood, R.D., 1976, Ecology of inland water and estuaries: New York, D. Van Nostrand Co., 485 p.

Rockers, J.J., Ratcliff, Ivan, Down, L.W., and Bouse, E.F., 1966, Soil survey of Reno County, Kansas: U.S. Soil Conservation Service, 72 p.

Sine, Charlotte, ed., 1993, Farm chemical handbook 1993: Willoughby, Ohio, Meister Publishing Co., variously numbered pages. 
14 Preliminary Assessment of Phosphorus Transport in the Cheney Reservoir Watershed, South-Central Kansas, $1997-98$ 


\section{SUPPLEMENTAL INFORMATION}


Table 4. Results of analyses of surface-water samples for total phosphorus from sampling sites in the Cheney Reservoir watershed, 1997-98

[M, manually collected sample; A, automatically collected sample; R, manually collected concurrent replicate sample; $\mathrm{ft}^{3} / \mathrm{s}$, cubic feet per second; $\mathrm{mg} / \mathrm{L}$, milligrams per liter]

\begin{tabular}{|c|c|c|c|c|c|}
\hline $\begin{array}{c}\text { Sampling-site } \\
\text { map index } \\
\text { number } \\
\text { (fig. 1) }\end{array}$ & $\begin{array}{c}\text { Date } \\
\text { (month/day/ } \\
\text { year) }\end{array}$ & $\begin{array}{c}\text { Time } \\
\text { (24-hour) }\end{array}$ & Sample type & $\begin{array}{c}\text { Streamflow } \\
\left(\mathrm{ft}^{3} / \mathrm{s}\right)\end{array}$ & $\begin{array}{c}\text { Total } \\
\text { phosphorus } \\
\text { concentration } \\
(\mathrm{mg} / \mathrm{L})\end{array}$ \\
\hline \multirow[t]{35}{*}{1} & $1 / 8 / 97$ & 1030 & $\bar{M}$ & 47 & 0.08 \\
\hline & $3 / 6 / 97$ & 1155 & M & 53 & .11 \\
\hline & $4 / 9 / 97$ & 1140 & $\mathrm{M}$ & 49 & .08 \\
\hline & $5 / 6 / 97$ & 1050 & M & 42 & .17 \\
\hline & $5 / 21 / 97$ & 1355 & M & 40 & .11 \\
\hline & $5 / 30 / 97$ & 1125 & A & 99 & .32 \\
\hline & $5 / 31 / 97$ & 0325 & A & 89 & .38 \\
\hline & & 1425 & A & 76 & .36 \\
\hline & & 1430 & $\mathrm{R}$ & 76 & .27 \\
\hline & $6 / 1 / 97$ & 0950 & A & 54 & .28 \\
\hline & $6 / 5 / 97$ & 1040 & M & 37 & .18 \\
\hline & $6 / 13 / 97$ & 1225 & A & 105 & .70 \\
\hline & $6 / 14 / 97$ & 0025 & A & 79 & .45 \\
\hline & & 1625 & A & 86 & .59 \\
\hline & $6 / 15 / 97$ & 0825 & A & 56 & .34 \\
\hline & $6 / 16 / 97$ & 1530 & A & 57 & .39 \\
\hline & $6 / 17 / 97$ & 0730 & A & 77 & .46 \\
\hline & $6 / 18 / 97$ & $1250^{\circ}$ & $\mathrm{R}$ & 72 & .29 \\
\hline & & 1255 & A & 72 & .42 \\
\hline & $6 / 19 / 97$ & 0130 & A & 58 & .30 \\
\hline & & 1330 & A & 53 & .33 \\
\hline & $6 / 20 / 97$ & 0135 & A & 46 & .28 \\
\hline & $6 / 24 / 97$ & 0235 & A & 44 & .45 \\
\hline & & 1435 & A & 131 & .66 \\
\hline & $6 / 25 / 97$ & 0635 & A & 110 & .57 \\
\hline & $6 / 26 / 97$ & 0025 & A & 87 & .44 \\
\hline & & 0955 & A & 102 & .41 \\
\hline & & 1020 & $\mathrm{R}$ & 105 & .35 \\
\hline & $7 / 9 / 97$ & 1230 & A & 46 & .43 \\
\hline & $7 / 10 / 97$ & 0125 & A & 41 & .31 \\
\hline & $7 / 24 / 97$ & 1035 & A & 51 & .54 \\
\hline & & 1225 & A & 48 & .30 \\
\hline & $7 / 25 / 97$ & 1245 & $\mathrm{R}$ & 33 & 1.3 \\
\hline & & 1250 & A & 33 & .30 \\
\hline & $8 / 11 / 97$ & 1130 & A & 93 & .54 \\
\hline
\end{tabular}


Table 4. Results of analyses of surface-water samples for total phosphorus from sampling sites in the Cheney Reservoir watershed, 1997-98-Continued

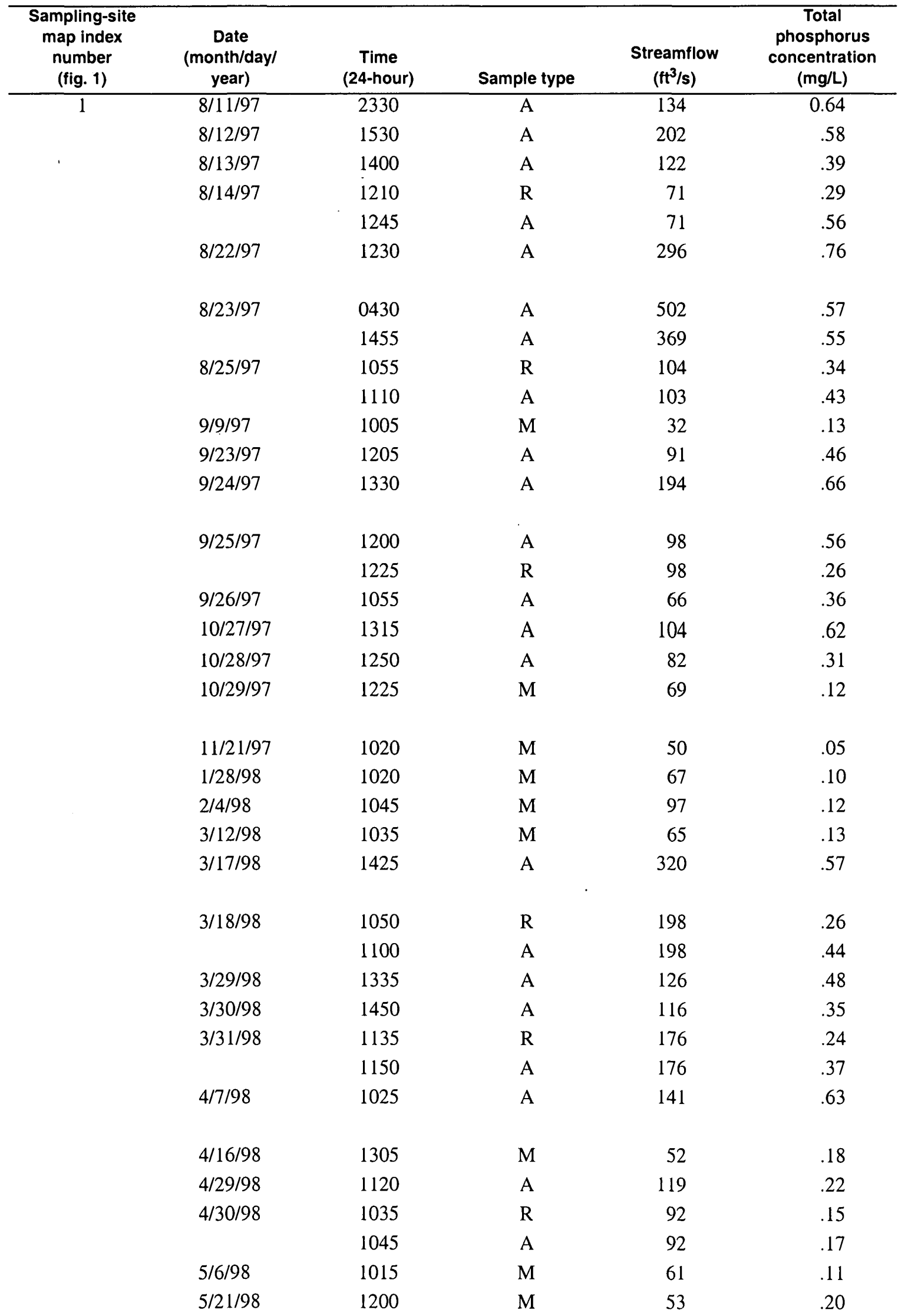


Table 4. Results of analyses of surface-water samples for total phosphorus from sampling sites in the Cheney Reservoir watershed, 1997-98-Continued

\begin{tabular}{|c|c|c|c|c|c|}
\hline $\begin{array}{l}\text { Sampling-site } \\
\text { map index } \\
\text { number } \\
\text { (fig. 1) }\end{array}$ & $\begin{array}{c}\text { Date } \\
\text { (month/day/ } \\
\text { year) }\end{array}$ & $\begin{array}{c}\text { Time } \\
\text { (24-hour) }\end{array}$ & Sample type & $\begin{array}{c}\text { Streamflow } \\
\left(\mathrm{ft}^{3} / \mathrm{s}\right)\end{array}$ & $\begin{array}{c}\text { Total } \\
\text { phosphorus } \\
\text { concentration } \\
(\mathrm{mg} / \mathrm{L})\end{array}$ \\
\hline \multirow[t]{34}{*}{1} & $6 / 3 / 98$ & 1045 & $\mathrm{M}$ & 35 & 0.18 \\
\hline & $6 / 23 / 98$ & 0335 & A & 107 & .47 \\
\hline & & 1305 & $\mathrm{R}$ & 151 & .60 \\
\hline & & 1325 & A & 151 & .60 \\
\hline & $7 / 7 / 98$ & 1040 & A & 82 & .39 \\
\hline & & 1115 & $\mathrm{R}$ & 82 & .41 \\
\hline & $7 / 8 / 98$ & 1330 & $\mathrm{R}$ & 54 & .22 \\
\hline & & 1350 & A & 54 & .24 \\
\hline & $7 / 10 / 98$ & 1040 & A & 58 & .05 \\
\hline & $7 / 16 / 98$ & 1035 & $\mathrm{M}$ & 43 & .12 \\
\hline & $7 / 27 / 98$ & 1145 & M & 32 & .10 \\
\hline & $8 / 12 / 98$ & 1020 & M & 24 & .11 \\
\hline & $8 / 26 / 98$ & 0935 & $\mathbf{M}$ & 16 & .07 \\
\hline & $9 / 9 / 98$ & 0935 & M & 15 & .02 \\
\hline & $9 / 28 / 98$ & 0210 & A & 103 & .40 \\
\hline & & 1210 & A & 176 & .76 \\
\hline & & 1515 & A & 161 & .46 \\
\hline & $9 / 29 / 98$ & 1150 & $\mathrm{R}$ & 62 & .23 \\
\hline & & 1220 & A & 62 & .33 \\
\hline & $10 / 2 / 98$ & 1310 & A & 212 & .48 \\
\hline & & 2115 & A & 114 & .20 \\
\hline & $10 / 3 / 98$ & 0915 & A & 78 & .36 \\
\hline & $10 / 4 / 98$ & 0115 & A & 56 & .22 \\
\hline & $10 / 17 / 98$ & 0750 & A & 58 & .04 \\
\hline & & 1955 & A & 176 & .53 \\
\hline & $10 / 18 / 98$ & 1155 & A & 64 & .23 \\
\hline & $10 / 31 / 98$ & 1035 & A & 77 & .18 \\
\hline & & 1435 & A & 92 & .30 \\
\hline & $11 / 1 / 98$ & 0635 & A & 513 & .61 \\
\hline & & 1400 & $\mathrm{R}$ & 494 & .43 \\
\hline & & 1415 & A & 494 & .63 \\
\hline & & 2245 & A & 493 & .46 \\
\hline & $11 / 2 / 98$ & 1045 & A & 497 & .59 \\
\hline & & 2045 & A & 395 & .42 \\
\hline & $11 / 3 / 98$ & 0845 & A & 306 & .13 \\
\hline & $11 / 4 / 98$ & 1235 & $\mathrm{R}$ & 260 & .30 \\
\hline & & 1250 & A & 260 & .32 \\
\hline
\end{tabular}


Table 4. Results of analyses of surface-water samples for total phosphorus from sampling sites in the Cheney Reservoir watershed, 1997-98-Continued

\begin{tabular}{|c|c|c|c|c|c|}
\hline $\begin{array}{l}\text { Sampling-site } \\
\text { map index } \\
\text { number } \\
\text { (fig. 1) }\end{array}$ & $\begin{array}{c}\text { Date } \\
\text { (month/day/ } \\
\text { year) }\end{array}$ & $\begin{array}{c}\text { Time } \\
\text { (24-hour) }\end{array}$ & Sample type & $\begin{array}{c}\text { Streamflow } \\
\left(\mathrm{ft}^{3} / \mathbf{s}\right)\end{array}$ & $\begin{array}{c}\text { Total } \\
\text { phosphorus } \\
\text { concentration } \\
\text { (mg/L) }\end{array}$ \\
\hline \multirow[t]{37}{*}{2} & $1 / 7 / 97$ & 1120 & $\bar{M}$ & 16 & 0.07 \\
\hline & $3 / 6 / 97$ & 1300 & M & 28 & .09 \\
\hline & $4 / 7 / 97$ & 1200 & $\mathbf{M}$ & 23 & .08 \\
\hline & $4 / 11 / 97$ & 1245 & A & 207 & .33 \\
\hline & $4 / 12 / 97$ & 1030 & A & 158 & .25 \\
\hline & $5 / 5 / 97$ & 1315 & $M$ & 16 & .05 \\
\hline & $5 / 21 / 97$ & 0950 & $\mathbf{M}$ & 104 & .34 \\
\hline & $5 / 30 / 97$ & 0940 & A & 67 & .35 \\
\hline & & 1325 & A & 70 & .28 \\
\hline & $5 / 31 / 97$ & 1100 & A & 70 & .31 \\
\hline & & 1105 & $\mathrm{R}$ & 70 & .28 \\
\hline & $6 / 4 / 97$ & 1225 & M & 28 & .20 \\
\hline & $6 / 24 / 97$ & 1315 & A & 260 & .65 \\
\hline & $6 / 25 / 97$ & 0120 & A & 71 & .37 \\
\hline & & 1325 & $\mathbf{M}$ & 57 & .39 \\
\hline & $7 / 8 / 97$ & 1110 & M & 15 & .19 \\
\hline & $7 / 18 / 97$ & 1140 & $\mathrm{M}$ & 6.3 & .23 \\
\hline & $7 / 22 / 97$ & 0055 & A & 56 & .47 \\
\hline & & 0655 & A & 86 & .59 \\
\hline & & 1155 & $\mathrm{R}$ & 128 & .60 \\
\hline & & 1320 & A & 131 & .54 \\
\hline & $7 / 23 / 97$ & 0130 & A & 99 & .45 \\
\hline & & 1330 & A & 63 & .45 \\
\hline & $8 / 11 / 97$ & 0725 & A & 47 & .76 \\
\hline & & 1325 & A & 101 & .78 \\
\hline & $8 / 12 / 97$ & 1115 & $\mathbf{M}$ & 29 & .29 \\
\hline & $8 / 22 / 97$ & 0355 & A & 53 & .89 \\
\hline & & 0955 & A & 145 & .84 \\
\hline & & 1625 & A & 83 & .54 \\
\hline & & 2225 & A & 72 & .36 \\
\hline & $8 / 26 / 97$ & 1100 & M & 22 & .22 \\
\hline & $9 / 10 / 97$ & 1055 & M & 8.2 & .10 \\
\hline & 9/23/97 & 2120 & A & 58 & .28 \\
\hline & $9 / 24 / 97$ & 0320 & A & 91 & .38 \\
\hline & $9 / 25 / 97$ & 1335 & A & 70 & .23 \\
\hline & & 1405 & $\mathrm{R}$ & 70 & .21 \\
\hline & $9 / 26 / 97$ & 0150 & A & 54 & .17 \\
\hline
\end{tabular}


Table 4. Results of analyses of surface-water samples for total phosphorus from sampling sites in the Cheney Reservoir watershed, 1997-98-Continued

\begin{tabular}{|c|c|c|c|c|c|}
\hline $\begin{array}{l}\text { Sampling-site } \\
\text { map index } \\
\text { number } \\
\text { (fig. 1) }\end{array}$ & $\begin{array}{c}\text { Date } \\
\text { (month/day/ } \\
\text { year) }\end{array}$ & $\begin{array}{c}\text { Time } \\
\text { (24-hour) }\end{array}$ & Sample type & $\begin{array}{c}\text { Streamflow } \\
\left(\mathrm{ft}^{3} / \mathrm{s}\right)\end{array}$ & $\begin{array}{c}\text { Total } \\
\text { phosphorus } \\
\text { concentration } \\
\text { (mg/L) }\end{array}$ \\
\hline \multirow[t]{37}{*}{2} & $10 / 27 / 97$ & 1230 & $\bar{A}$ & 63 & 0.20 \\
\hline & & 1240 & $\mathrm{R}$ & 63 & .16 \\
\hline & $11 / 19 / 97$ & 1200 & M & 22 & .04 \\
\hline & $1 / 27 / 98$ & 1335 & M & 35 & .06 \\
\hline & $2 / 5 / 98$ & 1130 & M & 55 & .06 \\
\hline & $3 / 10 / 98$ & 1210 & $\mathrm{M}$ & 52 & .10 \\
\hline & $3 / 17 / 98$ & 1055 & A & 338 & .26 \\
\hline & $3 / 18 / 98$ & 0955 & A & 324 & .25 \\
\hline & $3 / 23 / 98$ & 1140 & M & 232 & .14 \\
\hline & $3 / 29 / 98$ & 1400 & A & 127 & .14 \\
\hline & $3 / 30 / 98$ & 1410 & A & 96 & .15 \\
\hline & $3 / 31 / 98$ & 1040 & A & 111 & .12 \\
\hline & $4 / 1 / 98$ & 1415 & M & 89 & .11 \\
\hline & $4 / 7 / 98$ & 1000 & A & 99 & .14 \\
\hline & $4 / 14 / 98$ & 1220 & M & 36 & .08 \\
\hline & $4 / 29 / 98$ & 1200 & A & 78 & .18 \\
\hline & & 1205 & $\mathrm{R}$ & 78 & .16 \\
\hline & $5 / 5 / 98$ & 1125 & M & 27 & .10 \\
\hline & $5 / 20 / 98$ & 1155 & M & 20 & .08 \\
\hline & $6 / 2 / 98$ & 1115 & M & 7.9 & .10 \\
\hline & $6 / 26 / 98$ & 1040 & M & 3.9 & .12 \\
\hline & $7 / 2 / 98$ & 1235 & M & 15 & .33 \\
\hline & $7 / 14 / 98$ & 1230 & M & 5.0 & .16 \\
\hline & $7 / 28 / 98$ & 1140 & M & 3.8 & .13 \\
\hline & $8 / 11 / 98$ & 1130 & M & 1.5 & .14 \\
\hline & $8 / 25 / 98$ & 1305 & M & .24 & .20 \\
\hline & $9 / 8 / 98$ & 1145 & M & .10 & .21 \\
\hline & $9 / 30 / 98$ & 1200 & M & 10 & .13 \\
\hline & $10 / 31 / 98$ & 2030 & A & 43 & .23 \\
\hline & $11 / 1 / 98$ & 0430 & A & 254 & .47 \\
\hline & & 1320 & A & 308 & .33 \\
\hline & & 1635 & A & 384 & .36 \\
\hline & & 2035 & A & 530 & .42 \\
\hline & $11 / 2 / 98$ & 0435 & A & 573 & .24 \\
\hline & & 1635 & A & 481 & .27 \\
\hline & $11 / 3 / 98$ & 1215 & $\mathrm{R}$ & 278 & .29 \\
\hline & & 1235 & A & 278 & .20 \\
\hline
\end{tabular}


Table 4. Results of analyses of surface-water samples for total phosphorus from sampling sites in the Cheney Reservoir watershed, 1997-98-Continued

\begin{tabular}{|c|c|c|c|c|c|}
\hline $\begin{array}{l}\text { Sampling-site } \\
\text { map index } \\
\text { number } \\
\text { (fig. 1) }\end{array}$ & $\begin{array}{c}\text { Date } \\
\text { (month/day/ } \\
\text { year) }\end{array}$ & $\begin{array}{l}\text { Time } \\
\text { (24-hour) }\end{array}$ & Sample type & $\begin{array}{c}\text { Streamflow } \\
\left(\mathrm{ft}^{3} / \mathrm{s}\right)\end{array}$ & $\begin{array}{c}\text { Total } \\
\text { phosphorus } \\
\text { concentration } \\
(\mathrm{mg} / \mathrm{L})\end{array}$ \\
\hline 2 & $11 / 4 / 98$ & 1355 & $\bar{A}$ & 145 & 0.30 \\
\hline \multirow[t]{3}{*}{3} & $1 / 7 / 97$ & 1010 & M & 4.2 & .11 \\
\hline & $3 / 6 / 97$ & 1025 & M & 7.8 & .08 \\
\hline & $4 / 7 / 97$ & 1025 & M & 5.7 & .08 \\
\hline \multirow[t]{8}{*}{. } & $4 / 10 / 97$ & 1805 & A & 12 & .25 \\
\hline & $4 / 11 / 97$ & 1340 & A & 152 & .69 \\
\hline & $4 / 12 / 97$ & 1330 & A & 44 & .41 \\
\hline & $4 / 14 / 97$ & 1020 & A & 19 & .22 \\
\hline & $5 / 5 / 97$ & 1050 & M & 5.2 & .07 \\
\hline & $5 / 21 / 97$ & 1130 & M & 3.3 & .09 \\
\hline & $5 / 30 / 97$ & 1045 & A & 18 & .29 \\
\hline & & 2245 & A & 24 & .43 \\
\hline & $6 / 4 / 97$ & 1040 & M & 2.8 & .18 \\
\hline & $6 / 24 / 97$ & 0300 & A & 13 & 2.37 \\
\hline & & 1115 & $\mathrm{R}$ & 115 & .61 \\
\hline & & 1255 & A & 105 & .61 \\
\hline & & 1900 & A & 114 & .83 \\
\hline & $6 / 25 / 97$ & 0700 & A & 83 & .59 \\
\hline & $6 / 26 / 97$ & 0855 & A & 21 & .55 \\
\hline & $7 / 8 / 97$ & 0940 & $M$ & 3.5 & .18 \\
\hline & $7 / 17 / 97$ & 1120 & M & 2.6 & .12 \\
\hline & $7 / 22 / 97$ & 0945 & M & 11 & .59 \\
\hline & $8 / 11 / 97$ & 1150 & M & 130 & 1.1 \\
\hline & $8 / 12 / 97$ & 0950 & A & 100 & .74 \\
\hline & & 1300 & A & 92 & .68 \\
\hline & & 1900 & A & 76 & .69 \\
\hline & $8 / 13 / 97$ & 0700 & A & 33 & .54 \\
\hline & $8 / 22 / 97$ & 1345 & A & 92 & .69 \\
\hline & & 2145 & A & 103 & .69 \\
\hline & $8 / 23 / 97$ & 0545 & A & 84 & .57 \\
\hline & & 1745 & A & 41 & .51 \\
\hline & $8 / 26 / 97$ & 0940 & M & 7.7 & .29 \\
\hline & $9 / 10 / 97$ & 0940 & M & 2.9 & .08 \\
\hline & $9 / 23 / 97$ & 1310 & M & 7.6 & .33 \\
\hline & $9 / 24 / 97$ & 1310 & A & 58 & .52 \\
\hline & $9 / 25 / 97$ & 0110 & A & 60 & .54 \\
\hline & & 2110 & A & 41 & .54 \\
\hline
\end{tabular}


Table 4. Results of analyses of surface-water samples for total phosphorus from sampling sites in the Cheney Reservoir watershed, 1997-98-Continued

\begin{tabular}{|c|c|c|c|c|c|}
\hline $\begin{array}{c}\text { Sampling-site } \\
\text { map index } \\
\text { number } \\
\text { (fig. 1) }\end{array}$ & $\begin{array}{c}\text { Date } \\
\text { (month/day/ } \\
\text { year) }\end{array}$ & $\begin{array}{c}\text { Time } \\
\text { (24-hour) }\end{array}$ & Sample type & $\begin{array}{c}\text { Streamflow } \\
\left(\mathrm{ft}^{3} / \mathrm{s}\right)\end{array}$ & $\begin{array}{c}\text { Total } \\
\text { phosphorus } \\
\text { concentration } \\
(\mathrm{mg} / \mathrm{L})\end{array}$ \\
\hline \multirow[t]{31}{*}{3} & $9 / 26 / 97$ & 0910 & $\mathrm{~A}$ & 20 & 0.45 \\
\hline & $10 / 27 / 97$ & 1125 & M & 26 & .31 \\
\hline & $11 / 19 / 97$ & 1020 & M & 7.6 & .06 \\
\hline & $1 / 27 / 98$ & 1045 & M & 11 & .06 \\
\hline & $2 / 5 / 98$ & 1105 & M & 14 & .07 \\
\hline & $3 / 10 / 98$ & 1055 & M & 18 & .08 \\
\hline & $3 / 17 / 98$ & 1010 & A & 2.5 & .63 \\
\hline & $3 / 23 / 98$ & 1025 & M & 62 & .26 \\
\hline & $3 / 29 / 98$ & 1415 & A & 37 & .26 \\
\hline & $3 / 30 / 98$ & 1330 & A & 48 & .31 \\
\hline & $3 / 31 / 98$ & 1030 & A & 44 & .27 \\
\hline & $4 / 1 / 98$ & 1110 & M & 32 & .19 \\
\hline & $4 / 7 / 98$ & 0930 & A & 34 & .21 \\
\hline & $4 / 14 / 98$ & 1045 & M & 11 & .08 \\
\hline & $4 / 29 / 98$ & 1305 & M & 26 & .20 \\
\hline & $5 / 5 / 98$ & 1020 & M & 10 & .09 \\
\hline & $5 / 20 / 98$ & 1045 & M & 6.8 & .18 \\
\hline & $6 / 2 / 98$ & 0940 & M & 3.5 & .12 \\
\hline & $6 / 26 / 98$ & 0925 & M & 1.3 & .10 \\
\hline & $7 / 14 / 98$ & 1020 & M & 3.7 & .27 \\
\hline & $7 / 28 / 98$ & 1015 & M & 1.9 & .09 \\
\hline & $8 / 11 / 98$ & 0955 & M & .73 & .06 \\
\hline & $8 / 25 / 98$ & 0940 & M & .08 & .06 \\
\hline & $9 / 8 / 98$ & 1030 & M & .08 & .06 \\
\hline & $9 / 29 / 98$ & 1005 & M & 24 & .95 \\
\hline & $10 / 5 / 98$ & 1125 & M & 227 & .92 \\
\hline & $11 / 1 / 98$ & 1330 & A & 469 & .65 \\
\hline & $11 / 2 / 98$ & 1210 & A & 255 & .62 \\
\hline & $11 / 3 / 98$ & 1030 & $\mathrm{R}$ & 77 & .42 \\
\hline & & 1055 & A & 77 & .46 \\
\hline & $11 / 4 / 98$ & 1405 & A & 55 & .31 \\
\hline \multirow[t]{5}{*}{4} & $1 / 8 / 97$ & 1305 & M & 90 & .07 \\
\hline & $3 / 5 / 97$ & 1235 & M & 110 & .09 \\
\hline & $4 / 10 / 97$ & 1230 & M & 108 & .08 \\
\hline & & 1945 & A & 147 & .11 \\
\hline & $4 / 11 / 97$ & 0950 & A & 693 & .67 \\
\hline
\end{tabular}


Table 4. Results of analyses of surface-water samples for total phosphorus from sampling sites in the Cheney Reservoir watershed, 1997-98-Continued

\begin{tabular}{|c|c|c|c|c|c|}
\hline $\begin{array}{l}\text { Sampling-site } \\
\text { map index } \\
\text { number } \\
\text { (fig. 1) }\end{array}$ & $\begin{array}{c}\text { Date } \\
\text { (month/day/ } \\
\text { year) }\end{array}$ & $\begin{array}{c}\text { Time } \\
\text { (24-hour) }\end{array}$ & Sample type & $\begin{array}{c}\text { Streamflow } \\
\left(\mathrm{ft}^{3} / \mathrm{s}\right)\end{array}$ & $\begin{array}{c}\text { Total } \\
\text { phosphorus } \\
\text { concentration } \\
\text { (mg/L) }\end{array}$ \\
\hline \multirow[t]{37}{*}{4} & $4 / 12 / 97$ & 0935 & $\mathrm{~A}$ & 435 & 0.37 \\
\hline & $4 / 13 / 97$ & 0945 & $\mathrm{~A}$ & 270 & .24 \\
\hline & $5 / 7 / 97$ & 1055 & M & 76 & .13 \\
\hline & $5 / 20 / 97$ & 1525 & A & 138 & .33 \\
\hline & $5 / 21 / 97$ & 0325 & A & 235 & .48 \\
\hline & $5 / 22 / 97$ & 0930 & M & 120 & .21 \\
\hline & $6 / 6 / 97$ & 1145 & $M$ & 90 & .15 \\
\hline & $6 / 24 / 97$ & 0545 & A & 196 & 1.1 \\
\hline & & 1010 & A & 195 & .66 \\
\hline & & 2210 & A & 670 & .79 \\
\hline & $6 / 25 / 97$ & 1405 & A & 300 & 1.8 \\
\hline & $6 / 26 / 97$ & 1325 & M & 216 & .35 \\
\hline & & 1410 & A & 216 & .48 \\
\hline & $7 / 10 / 97$ & 1040 & M & 85 & .23 \\
\hline & $7 / 23 / 97$ & 1125 & M & 154 & .47 \\
\hline & $8 / 11 / 97$ & 1420 & A & 199 & .84 \\
\hline & $8 / 12 / 97$ & 0220 & A & 353 & .89 \\
\hline & & 1820 & A & 287 & .58 \\
\hline & $8 / 13 / 97$ & 1225 & $\mathrm{R}$ & 230 & .43 \\
\hline & & 1245 & A & 230 & .41 \\
\hline & $8 / 22 / 97$ & 1205 & A & 420 & 1.5 \\
\hline & $8 / 23 / 97$ & 0005 & A & 569 & .68 \\
\hline & $8 / 24 / 97$ & 0405 & A & 352 & .60 \\
\hline & $8 / 25 / 97$ & 1350 & A & 192 & .37 \\
\hline & & 1355 & $\mathrm{R}$ & 192 & .34 \\
\hline & 9/9/97 & 1310 & M & 50 & .12 \\
\hline & $9 / 23 / 97$ & 2320 & A & 200 & .37 \\
\hline & $9 / 24 / 97$ & 1415 & A & 638 & .68 \\
\hline & $9 / 25 / 97$ & 0220 & A & 686 & .42 \\
\hline & & 1005 & $\mathrm{R}$ & 448 & .31 \\
\hline & & 1035 & A & 448 & .64 \\
\hline & $10 / 27 / 97$ & 1340 & A & 206 & .02 \\
\hline & $10 / 30 / 97$ & 1215 & $\mathrm{M}$ & 121 & .12 \\
\hline & $11 / 21 / 97$ & 1225 & M & 93 & .06 \\
\hline & $1 / 29 / 98$ & 1110 & M & 144 & .07 \\
\hline & $2 / 4 / 98$ & 1335 & $\mathbf{M}$ & 208 & .11 \\
\hline & $3 / 12 / 98$ & 1305 & $\mathbf{M}$ & 135 & .11 \\
\hline
\end{tabular}


Table 4. Results of analyses of surface-water samples for total phosphorus from sampling sites in the Cheney Reservoir watershed, 1997-98-Continued

\begin{tabular}{|c|c|c|c|c|c|}
\hline $\begin{array}{l}\text { Sampling-site } \\
\text { map index } \\
\text { number } \\
\text { (fig. 1) }\end{array}$ & $\begin{array}{c}\text { Date } \\
\text { (month/day/ } \\
\text { year) }\end{array}$ & $\begin{array}{c}\text { Time } \\
\text { (24-hour) }\end{array}$ & Sample type & $\begin{array}{c}\text { Streamflow } \\
\left(\mathrm{ft}^{3} / \mathrm{s}\right)\end{array}$ & $\begin{array}{c}\text { Total } \\
\text { phosphorus } \\
\text { concentration } \\
\text { (mg/L) }\end{array}$ \\
\hline \multirow[t]{36}{*}{4} & $3 / 17 / 98$ & 1530 & $\mathrm{~A}$ & 1,360 & 0.44 \\
\hline & $3 / 18 / 98$ & 1335 & M & 911 & .31 \\
\hline & $3 / 29 / 98$ & 1305 & A & 391 & .20 \\
\hline & $3 / 31 / 98$ & 1315 & M & 414 & .20 \\
\hline & $4 / 7 / 98$ & 1110 & A & 352 & .21 \\
\hline & $4 / 17 / 98$ & 1225 & M & 140 & .12 \\
\hline & $4 / 28 / 98$ & 1205 & A & 179 & .09 \\
\hline & $4 / 30 / 98$ & 1220 & A & 234 & .19 \\
\hline & & 1245 & $\mathrm{R}$ & 234 & .14 \\
\hline & $5 / 7 / 98$ & 1025 & M & 132 & .08 \\
\hline & $5 / 22 / 98$ & 1135 & M & 92 & .14 \\
\hline & $6 / 4 / 98$ & 1430 & M & 76 & .12 \\
\hline & $6 / 23 / 98$ & 1545 & A & 158 & .55 \\
\hline & $6 / 24 / 98$ & 1055 & M & 105 & .27 \\
\hline & $7 / 9 / 98$ & 1050 & $\mathrm{R}$ & 173 & .29 \\
\hline & & 1105 & A & 173 & .37 \\
\hline & & 1405 & A & 167 & .38 \\
\hline & & 1500 & A & 167 & .16 \\
\hline & $7 / 13 / 98$ & 1035 & M & 78 & .21 \\
\hline & $7 / 29 / 98$ & 1015 & M & 45 & .09 \\
\hline & $8 / 13 / 98$ & 1130 & M & 32 & .10 \\
\hline & $8 / 27 / 98$ & 0920 & M & 17 & .06 \\
\hline & $9 / 9 / 98$ & 1245 & M & 12 & .06 \\
\hline & $9 / 27 / 98$ & 2220 & A & 87 & 1.2 \\
\hline & $9 / 29 / 98$ & 1400 & A & 99 & .04 \\
\hline & $9 / 30 / 98$ & 1010 & $\mathrm{R}$ & 92 & .30 \\
\hline & & 1015 & A & 92 & .30 \\
\hline & $10 / 1 / 98$ & 1110 & A & 86 & .18 \\
\hline & $10 / 2 / 98$ & 1130 & A & 122 & .28 \\
\hline & $10 / 3 / 98$ & 0025 & A & 171 & .35 \\
\hline & $10 / 4 / 98$ & 0825 & A & 109 & .23 \\
\hline & $10 / 5 / 98$ & 2240 & A & 246 & .60 \\
\hline & $10 / 7 / 98$ & 0640 & A & 101 & .24 \\
\hline & $11 / 1 / 98$ & 1240 & A & 2,010 & .66 \\
\hline & & 1500 & A & 2,260 & .56 \\
\hline & & 2300 & A & 2,060 & .58 \\
\hline
\end{tabular}


Table 4. Results of analyses of surface-water samples for total phosphorus from sampling sites in the Cheney Reservoir watershed, 1997-98-Continued

\begin{tabular}{|c|c|c|c|c|c|}
\hline $\begin{array}{l}\text { Sampling-site } \\
\text { map index } \\
\text { number } \\
\text { (fig. 1) }\end{array}$ & $\begin{array}{c}\text { Date } \\
\text { (month/day/ } \\
\text { year) }\end{array}$ & $\begin{array}{c}\text { Time } \\
\text { (24-hour) }\end{array}$ & Sample type & $\begin{array}{c}\text { Streamflow } \\
\left(\mathrm{ft}^{3} / \mathrm{s}\right)\end{array}$ & $\begin{array}{c}\text { Total } \\
\text { phosphorus } \\
\text { concentration } \\
\text { (mg/L) }\end{array}$ \\
\hline \multirow[t]{8}{*}{4} & $11 / 2 / 98$ & 0700 & $\mathrm{~A}$ & 2,140 & 0.40 \\
\hline & & 1425 & $\mathrm{R}$ & 1,860 & .36 \\
\hline & & 1445 & $\mathrm{~A}$ & 1,860 & .35 \\
\hline & & 2335 & A & 1,500 & .39 \\
\hline & $11 / 3 / 98$ & 0735 & A & 1,230 & .34 \\
\hline & & 2235 & A & 763 & .34 \\
\hline & $11 / 4 / 98$ & 1010 & M & 568 & .32 \\
\hline & $12 / 15 / 98$ & 1250 & M & 106 & .10 \\
\hline \multirow[t]{30}{*}{5} & $1 / 8 / 97$ & 1140 & M & 3.2 & .04 \\
\hline & $3 / 6 / 97$ & 1020 & $\mathrm{M}$ & 4.0 & .08 \\
\hline & $4 / 9 / 97$ & 1005 & M & 3.5 & .08 \\
\hline & $4 / 11 / 97$ & 1100 & A & 100 & .64 \\
\hline & $5 / 6 / 97$ & 1355 & $\mathrm{M}$ & 3.2 & .11 \\
\hline & $5 / 22 / 97$ & 1105 & M & 1.8 & .12 \\
\hline & $6 / 5 / 97$ & 1220 & M & 2.3 & .17 \\
\hline & $6 / 13 / 97$ & 1025 & $\mathrm{~A}$ & 55 & 1.2 \\
\hline & & 1200 & $\mathrm{~A}$ & 48 & 1.1 \\
\hline & & 1800 & $\mathrm{~A}$ & 26 & .79 \\
\hline & $6 / 16 / 97$ & 0950 & A & 654 & 1.4 \\
\hline & & 1040 & M & 569 & 1.2 \\
\hline & & 1120 & A & 511 & 1.2 \\
\hline & & 1445 & A & 280 & 1.1 \\
\hline & & 2040 & A & 123 & 1.0 \\
\hline & $6 / 24 / 97$ & 1410 & A & 295 & .81 \\
\hline & & 1615 & A & 229 & .80 \\
\hline & & 2015 & A & 204 & .94 \\
\hline & $6 / 25 / 97$ & 0215 & A & 99 & 1.2 \\
\hline & & 1005 & M & 71 & .94 \\
\hline & $7 / 9 / 97$ & 0940 & $\mathrm{R}$ & 31 & .87 \\
\hline & & 0945 & A & 31 & .82 \\
\hline & & 1255 & $\mathrm{~A}$ & 19 & .79 \\
\hline & & 1655 & A & 12 & .70 \\
\hline & & 2255 & $\mathrm{~A}$ & 7.8 & .53 \\
\hline & $7 / 10 / 97$ & 0455 & A & 6.1 & .45 \\
\hline & $7 / 23 / 97$ & 0935 & M & 1.3 & .21 \\
\hline & $7 / 31 / 97$ & 1325 & M & .80 & .19 \\
\hline & $8 / 13 / 97$ & 0935 & $\mathrm{M}$ & 1.0 & .18 \\
\hline & $8 / 22 / 97$ & 0740 & $\mathrm{~A}$ & 12 & .52 \\
\hline
\end{tabular}


Table 4. Results of analyses of surface-water samples for total phosphorus from sampling sites in the Cheney Reservoir watershed, 1997-98-Continued

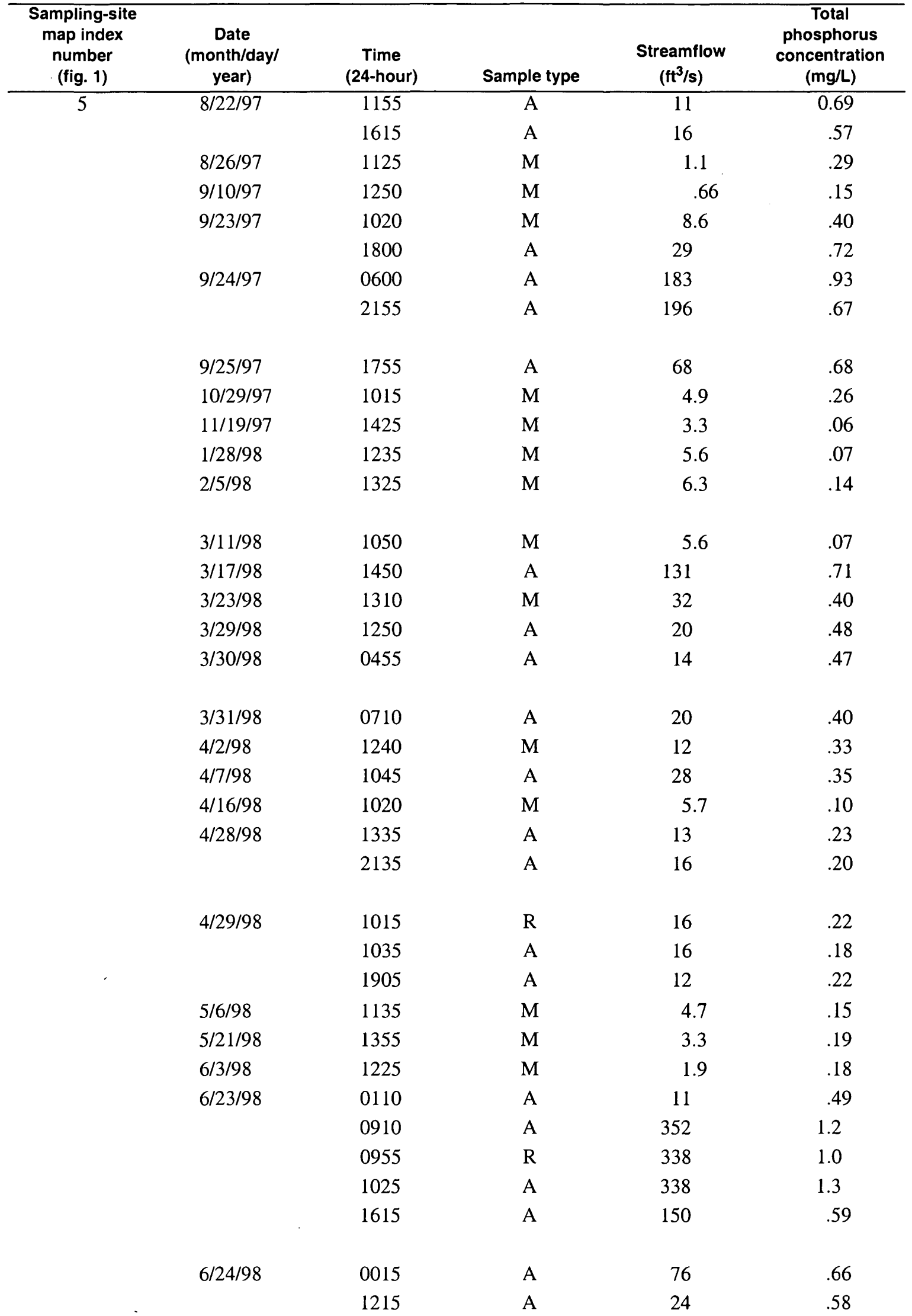


Table 4. Results of analyses of surface-water samples for total phosphorus from sampling sites in the Cheney Reservoir watershed, 1997-98-Continued

\begin{tabular}{|c|c|c|c|c|c|}
\hline $\begin{array}{c}\text { Sampling-site } \\
\text { map index } \\
\text { number } \\
\text { (fig. 1) }\end{array}$ & $\begin{array}{c}\text { Date } \\
\text { (month/day/ } \\
\text { year) }\end{array}$ & $\begin{array}{c}\text { Time } \\
\text { (24-hour) }\end{array}$ & Sample type & $\begin{array}{l}\text { Streamflow } \\
\left(\mathrm{ft}^{3} / \mathrm{s}\right)\end{array}$ & $\begin{array}{c}\text { Total } \\
\text { phosphorus } \\
\text { concentration } \\
\text { (mg/L) }\end{array}$ \\
\hline \multirow[t]{38}{*}{5} & $6 / 24 / 98$ & 1620 & $\mathrm{~A}$ & 18 & 0.49 \\
\hline & & 2220 & A & 13 & .49 \\
\hline & $7 / 7 / 98$ & 0615 & A & 11 & .48 \\
\hline & & 1340 & $\mathrm{R}$ & 66 & .74 \\
\hline & & 1400 & A & 66 & .77 \\
\hline & & 2010 & A & 133 & .72 \\
\hline & $7 / 8 / 98$ & 0210 & A & 88 & .76 \\
\hline & & 1010 & A & 53 & .59 \\
\hline & & 1055 & $\mathrm{R}$ & 52 & .60 \\
\hline & & 1135 & A & 52 & .56 \\
\hline & & 2335 & $\mathrm{~A}$ & 20 & .44 \\
\hline & $7 / 9 / 98$ & 0735 & $\mathrm{~A}$ & 104 & .70 \\
\hline & & 1250 & $\mathbf{R}$ & 131 & .46 \\
\hline & $7 / 9 / 98$ & 1300 & $\mathrm{~A}$ & 131 & .63 \\
\hline & & 2105 & A & 66 & .13 \\
\hline & $7 / 10 / 98$ & 0305 & A & 48 & .68 \\
\hline & & 1105 & A & 27 & .55 \\
\hline & $7 / 16 / 98$ & 1210 & M & 3.3 & .19 \\
\hline & $7 / 27 / 98$ & 1025 & M & 2.1 & .19 \\
\hline & $8 / 12 / 98$ & 1140 & M & 1.1 & .11 \\
\hline & $8 / 26 / 98$ & 1145 & M & .51 & .12 \\
\hline & $9 / 9 / 98$ & 1045 & M & .42 & .12 \\
\hline & $9 / 28 / 98$ & 0125 & A & 72 & .64 \\
\hline & & 0925 & A & 25 & .73 \\
\hline & & 0950 & $\mathrm{R}$ & 30 & .58 \\
\hline & $9 / 29 / 98$ & 0250 & A & 10 & .70 \\
\hline & $9 / 30 / 98$ & 0940 & A & 18 & .69 \\
\hline & & 1340 & A & 18 & .61 \\
\hline & $10 / 2 / 98$ & 1100 & A & 91 & .02 \\
\hline & & 2130 & A & 60 & .60 \\
\hline & $10 / 5 / 98$ & 1850 & A & 26 & .55 \\
\hline & $10 / 6 / 98$ & 1710 & A & 11 & .43 \\
\hline & $11 / 1 / 98$ & 1215 & A & 998 & 1.3 \\
\hline & & 1440 & A & 1,040 & .98 \\
\hline & $11 / 2 / 98$ & 1010 & A & 590 & .67 \\
\hline & & 1215 & A & 455 & .58 \\
\hline & & 1315 & $\mathrm{R}$ & 402 & .60 \\
\hline & & 1410 & A & 402 & .57 \\
\hline
\end{tabular}


Table 4. Results of analyses of surface-water samples for total phosphorus from sampling sites in the Cheney Reservoir watershed, 1997-98-Continued

\begin{tabular}{|c|c|c|c|c|c|}
\hline $\begin{array}{l}\text { Sampling-site } \\
\text { map index } \\
\text { number } \\
\text { (fig. 1) }\end{array}$ & $\begin{array}{c}\text { Date } \\
\text { (month/day/ } \\
\text { year) }\end{array}$ & $\begin{array}{c}\text { Time } \\
\text { (24-hour) }\end{array}$ & Sample type & $\begin{array}{c}\text { Streamflow } \\
\left(\mathrm{ft}^{3} / \mathrm{s}\right)\end{array}$ & $\begin{array}{c}\text { Total } \\
\text { phosphorus } \\
\text { concentration } \\
\text { (mg/L) }\end{array}$ \\
\hline \multirow[t]{2}{*}{5} & $11 / 3 / 98$ & 1415 & $\mathrm{~A}$ & 114 & 0.56 \\
\hline & $11 / 4 / 98$ & 1135 & A & 44 & .51 \\
\hline \multirow[t]{33}{*}{6} & $1 / 7 / 97$ & 1325 & M & 490 & .16 \\
\hline & $2 / 10 / 97$ & 0950 & $\mathbf{M}$ & 241 & .14 \\
\hline & $3 / 5 / 97$ & 1005 & $\mathrm{M}$ & 257 & .16 \\
\hline & $3 / 19 / 97$ & 0950 & M & .28 & .16 \\
\hline & $4 / 10 / 97$ & 0935 & $\mathrm{M}$ & .56 & .06 \\
\hline & $4 / 15 / 97$ & 0940 & M & 267 & .07 \\
\hline & $4 / 21 / 97$ & 0935 & $\mathbf{M}$ & 865 & .06 \\
\hline & $4 / 29 / 97$ & 0855 & $\mathbf{M}$ & .97 & .05 \\
\hline & $5 / 7 / 97$ & 1340 & $\mathbf{M}$ & 1.0 & .06 \\
\hline & $5 / 15 / 97$ & 0955 & $\mathbf{M}$ & 1.0 & .06 \\
\hline & $5 / 22 / 97$ & 1405 & $\mathbf{M}$ & .47 & .08 \\
\hline & $5 / 27 / 97$ & 1125 & $\mathbf{M}$ & .45 & .10 \\
\hline & $6 / 6 / 97$ & 0900 & $\mathbf{M}$ & .47 & .08 \\
\hline & $6 / 18 / 97$ & 0910 & M & .47 & .07 \\
\hline & $6 / 23 / 97$ & 1230 & $\mathbf{M}$ & 18 & .14 \\
\hline & $7 / 1 / 97$ & 1010 & $\mathbf{M}$ & .42 & .13 \\
\hline & $7 / 10 / 97$ & 1305 & M & 582 & .14 \\
\hline & $7 / 17 / 97$ & 0915 & M & 231 & .16 \\
\hline & $7 / 25 / 97$ & 0945 & $\mathbf{M}$ & .20 & .14 \\
\hline & $7 / 31 / 97$ & 1040 & $\mathbf{M}$ & .23 & .12 \\
\hline & $8 / 7 / 97$ & 0955 & M & .32 & .14 \\
\hline & $8 / 22 / 97$ & 1035 & $\mathbf{M}$ & .39 & .14 \\
\hline & $8 / 29 / 97$ & 1035 & $\mathbf{M}$ & 252 & .11 \\
\hline & $9 / 11 / 97$ & 0900 & M & .42 & .14 \\
\hline & $9 / 29 / 97$ & 1300 & M & .28 & .14 \\
\hline & $10 / 17 / 97$ & 1010 & M & 238 & .15 \\
\hline & $10 / 29 / 97$ & 1355 & M & 254 & .14 \\
\hline & $11 / 25 / 97$ & 1100 & M & .24 & .15 \\
\hline & $12 / 12 / 97$ & 1015 & M & 90 & .12 \\
\hline & $1 / 29 / 98$ & 1305 & M & 255 & .15 \\
\hline & $2 / 26 / 98$ & 1020 & M & 122 & .10 \\
\hline & $3 / 13 / 98$ & 1020 & M & 1.6 & .10 \\
\hline & $3 / 27 / 98$ & 1105 & $\mathbf{M}$ & 842 & .10 \\
\hline
\end{tabular}


Table 4. Results of analyses of surface-water samples for total phosphorus from sampling sites in the Cheney Reservoir watershed, 1997-98-Continued

\begin{tabular}{|c|c|c|c|c|c|}
\hline $\begin{array}{l}\text { Sampling-site } \\
\text { map index } \\
\text { number } \\
\text { (fig. 1) }\end{array}$ & $\begin{array}{c}\text { Date } \\
\text { (month/day/ } \\
\text { year) }\end{array}$ & $\begin{array}{c}\text { Time } \\
\text { (24-hour) }\end{array}$ & Sample type & $\begin{array}{c}\text { Streamflow } \\
\left(\mathrm{ft}^{3} / \mathrm{s}\right)\end{array}$ & $\begin{array}{c}\text { Total } \\
\text { phosphorus } \\
\text { concentration } \\
\text { (mg/L) }\end{array}$ \\
\hline \multirow[t]{25}{*}{6} & $4 / 2 / 98$ & 0950 & $\mathrm{M}$ & 1,320 & 0.09 \\
\hline & $4 / 17 / 98$ & 1025 & M & 245 & .08 \\
\hline & $4 / 21 / 98$ & 1045 & M & 24 & .06 \\
\hline & $4 / 30 / 98$ & 1450 & M & 245 & .08 \\
\hline & $5 / 7 / 98$ & 1220 & M & 159 & .07 \\
\hline & $5 / 15 / 98$ & 1110 & M & 111 & .10 \\
\hline & $5 / 22 / 98$ & 1350 & M & 1.5 & .07 \\
\hline & $5 / 29 / 98$ & 0950 & M & 1.5 & .07 \\
\hline & $6 / 4 / 98$ & 0950 & M & 1.8 & .09 \\
\hline & $6 / 10 / 98$ & 0930 & M & 1.5 & .10 \\
\hline & $6 / 18 / 98$ & 1125 & $\mathbf{M}$ & 1.9 & .12 \\
\hline & $6 / 25 / 98$ & 1240 & M & 1.3 & .12 \\
\hline & $7 / 6 / 98$ & 1020 & M & .83 & .10 \\
\hline & $7 / 13 / 98$ & 1250 & M & .49 & .09 \\
\hline & $7 / 24 / 98$ & 0950 & M & .32 & .07 \\
\hline & $7 / 29 / 98$ & 1225 & M & .32 & .09 \\
\hline & $8 / 7 / 98$ & 1145 & M & .32 & .08 \\
\hline & $8 / 14 / 98$ & 1130 & $\mathrm{M}$ & .33 & .06 \\
\hline & $8 / 21 / 98$ & 0935 & M & .20 & .09 \\
\hline & $8 / 27 / 98$ & 1230 & M & .26 & .09 \\
\hline & 9/10/98 & 1015 & M & .36 & .10 \\
\hline & $10 / 1 / 98$ & 1215 & M & .38 & .11 \\
\hline & $11 / 10 / 98$ & 1015 & M & 986 & .18 \\
\hline & $11 / 24 / 98$ & 1040 & M & 110 & .16 \\
\hline & $12 / 16 / 98$ & 1110 & M & 217 & .18 \\
\hline
\end{tabular}


